\title{
Syntax or Phonology? Proclitics, Enclitics, and Stress in Hittite*
}

\begin{abstract}
The paper deals with the syntax of mān “if", namma "then", našma "or", perfectivising kāšal $k \bar{a} s ̌ m a$, relative and indefinite pronouns as well as some subordinators in Hittite against the background of other Indo-European languages, particularly Latin and Greek. It has been recently proposed that their position in the clause and syntactic behaviour are either partially or fully determined by their being either proclitics or enclitics. We review the proposals and argue that purely phonological rules are highly unlikely for any of the constituents. A purely syntactic account is put forward to fully capture the data. It is particularly noteworthy that from the IE perspective Hittite is radically different from Narrow IE languages (like Old Greek) where indefinite pronouns are normally unstressed: all the Hittite data which are at first sight similar to Narrow IE turn out to be secondary independent innovations of Hittite and cannot serve as the basis of Indo-Hittite reconstruction.
\end{abstract}

Keywords: syntax, second position, enclitics, proclitics, stress, relative pronouns, indefinite pronouns.

\section{Introduction}

Recently there has been a positive flood of studies independently proposing prosodic solutions for syntactic phenomena in Hittite [Kloekhorst 2014; Huggard 2014; Becker 2014]. Three groups of words have been discussed: (a) mān "if", kui- "which" in indeterminate clauses, namma "then”, našma "or", perfectivising kāšal kāšma; (b) relative pronouns; (c) indefinite pronouns. In the paper we will reexamine the data from synchronical and diachronical Hittite perspective as well as against the background of other IE languages, primarily Latin and Greek, and show that their syntactic behaviour is determined not by prosody, but rather by syntax. Comparing the Hittite data to those of Greek and Latin, we suggest that the features at first sight identical in Hittite and Narrow IE languages should be assessed as independent innovations.

\section{Hittite Proclitics}

Standardly, only sentence connectives like $n u, t a, \breve{s} u$ are analyzed as proclitics in Hittite, i.e. as words that form one phonological word with the following fully stressed word, see for an overview most recently [Kloekhorst 2014]. Kloekhorst proposes to broaden the class of Hittite proclitics from sentence connectives $n u, s ̌ u$, ta to all the constituents that delay contrastively

* The research of A. Sideltsev and M. Molina is supported by the Russian Academy of Sciences under the 'Corpus Linguistics' program. The research of A. Belov is supported by the Council for Grants under the President of the Russian Federation, Grant \#MД-6027.2014.6.

Journal of Language Relationship • Вопросы языкового родства • 13/2 (2015) • Pp. 139-168 • ㅇ The authors, 2015 
topicalizing particle - $(m) a$ to the next stressed word. These are mān "if", kui- "which" in indeterminate clauses ${ }^{1}$, namma "then”, našma “or”, perfectivising kā̌šal kāšma.

The argument is based on the parallel behaviour of the prototypical proclitic $n u$, on the one hand, and mān etc, on the other. ${ }^{2}$

(a) Prototypical proclitics like $n u$ etc. host prototypical Wackernagel enclitics, as illustrated by ${ }^{3}$ :

(1) OH-MH/MS (CTH 262) IBoT 1.36 obv. i 20-21

$n=\underline{a s ̌ t a} \quad m \bar{a} n$ GI appezziš DUMU É.GAL parā ue-zzi \#

CONN=LOC if reed last palace servant out come-3SG.PRS

"Then if a low-ranking palace servant comes out (for) reed".

It is perfectly well known that prototypical proclitics do not host topicalizing/contrastive $-(m) a$ delaying it to the next word:

(2) $\mathrm{OH} / \mathrm{OS}$ (CTH 1.A) KBo 3.22 obv. 3

$\begin{array}{lllll}n=a s ̌ t a & \text { DIM-unn- } i=m a & m \bar{a} n & \bar{a} \check{s} s ̌ u-s ̌ & \bar{e} s ̌-t a \# \\ \text { CONN=LOC } & \text { Stormgod-DAT.SG=but } & \text { when } & \text { dear-NOM.SG.C } & \text { be-3sG.PST }\end{array}$

"And when he was dear to the Stormgod" (following [CHD L-N: 148]).

What is not usually taken notice of ${ }^{4}$ is that proclitics do not count either when the second position of relative pronouns in determinate relative clauses, some subordinators like kuit "as" (see now [Huggard 2013]) and mahhan "as"5 as well as indefinite pronouns is calculated:

(3) OH-MH/MS (CTH 262) IBoT 1.36 obv. i 61-62

$\begin{array}{llllll}n u & 1 & \text { LúMEŠEDI } & k u i-s ̌ & \text { šarkanti-n } & \text { widāi-zzi \# } \\ \text { CONN } & 1 & \text { bodyguard } & \text { who-NOM.SG.C } & \text { petitioner-ACC.SG.C } & \text { bring-3sG.PRS }\end{array}$

"A bodyguard who brings a petitioner, ...".

(4) $\mathrm{OH}-\mathrm{MH} / \mathrm{MS}$ (CTH 262) IBoT 1.36 obv. i 22-23

nu GAL MEŠEDI kuit GIŠGIDRU har-zi \#

CONN chief bodyguard since staff hold-3sG.PRS

"Since the chief of the bodyguard holds a staff".

(5) MH/NS (CTH 259.B) KUB 13.20 obv. i 30-31

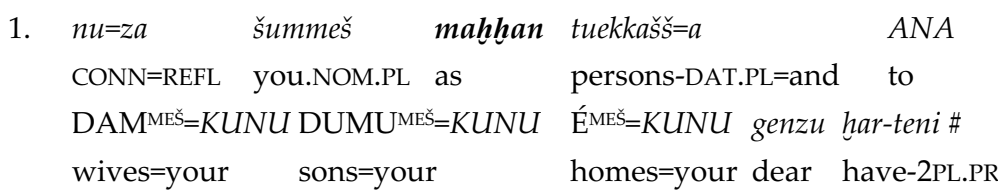

${ }^{1}$ As is standardly assumed in the current Hittitological tradition going back to [Held 1957], kui- "which" in determinate clauses is clause second and thus is irrelevant for the placement of -ma. Cf. [Becker 2014].

2 The word the usage of which we illustrate with the example is in bold. The underlined word marks the second relevant word in citation. Sign \# marks the end of the clause. Italic marks text in Hittite, all caps mark Sumerograms, all caps in italic mark Akkadograms.

${ }^{3}$ We draw examples mostly from our database of Hittite syntax and information structure. At present it includes $\mathrm{MH} / \mathrm{MS}$ letters and instructions.

${ }^{4}$ But cf. now [Becker 2014: 101], without observing the parallelisms between relative pronouns and -ma.

${ }^{5}$ The subordinator is not normally assessed as second position, see [CHD L-N sub mahhan]. However, there are a number of attestations which can only be assessed as indicating second position, see [Hoffner, Melchert 2008: 417] and below. 


\section{LUGAL-uwaš šakli-ya genzu QATAMMA har-ten \# \\ king.GEN.PL imperative-DAT.SG affection thus have-2PL.IMP}

“(1) And just as you hold dear (your own) persons, your wives, your sons (and) your homes, (2) you shall also feel affection for the imperative of the king" (following [Miller 2013: 150-1]).

(6) $\mathrm{OH}-\mathrm{MH} / \mathrm{MS}$ (CTH 262) IBoT 1.36 obv. iv 8

[nu] LÚMEš ̌̌UKUR māhhhan hilammar arha takšan šarr-i \#

CONN spear-men when gatehouse away middle pass-3sG.PRS

"[And] as soon as the spear-men pass through the middle of the gatehouse..." (following [Miller 2013: 118-9]).

(b) Just like $n u$, constituents like $m \bar{a} n$ "if" host Wackernagel enclitics, too, but not $-(m) a$. The same class of constituents does not count when the second position of relative pronouns in determinate relative clauses, subordinators kuit and mahhan "as" and indefinite pronouns is calculated:

(7) $\mathrm{OH}-\mathrm{MH} / \mathrm{MS}$ (CTH 262) IBoT 1.36 obv. i 57

$m \bar{a} n=\underline{w a}=[k a] n$ šarā=ma kui-š antūwahha-š handāi-zzi \#

if=QUOT=LOC up=but some-NOM.SG.C man-NOM.SG.C manage-3SG.PRS

"if some man manages (to go) up".

(8) NH/NS (CTH 62.A) KBo 5.9+ rev. iii 7

mān memiya- ̌s=ma $\quad \underline{k u i-\check{s}} \quad$ iya-uwa- $\check{s} \#$

if matter-NOM.SG.C=but which-NOM.SG.C do-INFIN-GEN.SG

"But if it is a matter which needs to be done, ..." (following [G. Wilhelm - F. Fuscagni (ed.), hethiter.net/: CTH 62 (TX 16.10.2013, TRde 15.10.2013)]; cf. [Held 1957: 41, Beckman 1996: 57]).

(9) $\mathrm{OH}-\mathrm{MH} / \mathrm{MS}$ (CTH 262) IBoT 1.36 obv. i 50

našma $=w a=k a n \quad k a t t a=m a \quad$ it \#

or $=\mathrm{QUOT}=\mathrm{LOC} \quad$ down=BUT go.IMP.2SG

"Or you go down!".

(10) OH-MH/MS (CTH 262) IBoT 1.36 rev. iv 22-23

nu kui-šsúMEŠEDI=ma ar-ta \#

CONN which-NOM.SG.C bodyguard=but stand-3sG.PRS

"Then whatever bodyguard is standing there".

(11) $\mathrm{MH} ? / \mathrm{NS}$ (CTH 258.1.A) KUB 13.9 obv. ii 3-4

mān ēšhan-ašš=a kuiški šarnikzil piy-an har-zi \#

if blood-GEN.SG=and someone.NOM.SG.C compensation.ACC.SG.N give-PRTC.NOM.SG.N have-3SG.PRS

"If someone has paid compensation for blood(shed), too, ..." (following [Miller 2013: 136-7]).

(12) OH-MH/MS (CTH 262) IBoT 1.36 obv. ii 63

$m \bar{a} n=\check{s} i$ peran=ma kuwapi KASKAL-i-š hatku-š \#

if=him ahead=but where road-NOM.SG.C narrow-NOM.SG.C

"If the road ahead is at some point too narrow for him, ..." (following [Miller 2013: 112-3]).

[Kloekhorst 2014] summarizes the existing literature on the points above and comes to the conclusion that the data can only be interpreted as not only $n u$ being unstressed and proclitic, but also the class comprising $m \bar{a} n$ "if" etc. Thus it is assumed that $-(m) a$ is the only clitic which imposes the constraint on its host that it must bear stress or accent; see generally [Halpern 1996: xi] for an overview of similar accounts in phonological terms. However, the account is simply circular: $-(m) a$ is different from other clitics just because it is different. 
In the cross-linguistic perspective, which is not considered in [Kloekhorst 2014], such cases where a given word may host one class of clitics, but not another, are quite frequently described [Halpern 1996: xi]. The cases are termed clitic cluster split: some clusterizing clitics are in the clausal second position while other clusterizing clitics show up in the next position to the right of it, see, e.g., for Slavic languages [Zaliznjak 2008, Zimmerling, Kosta 2013, Zimmerling 2013], for West Flemish [Haegeman 1996: 153, 155-8].

We will illustrate it by a few examples. In Bulgarian clitic cluster split occurs with future tense proclitic šte and negation marker ne: they host all the clitics, but not the question particle li which is, in linear terms, delayed to the next word [Zimmerling, Kosta 2013: 197-8]:

(13) Ще миго продадеш ми този часовник?
FUT.PRTC meit sell.2sG.FUT Q this watch
"Will you sell me this watch?"6

In Macedonian clitic cluster splits if clitics are hosted by the negation marker ne: it hosts auxiliary clitics, but not pronominal ones, the latter move one step to the right [Zimmerling, Kosta 2013: 197-8]. For Old Russian two groups of enclitics are delimited: strong enclitics, which very seldom occur outside of Wackernagel position, and weak enclitics, which occur outside this position much more frequently [Zaliznjak 2008: 51-52]. If the clitic cluster is not split, in the majority of cases the strong enclitics precede weak ones in the enclitic chain. If there is a cluster split, strong clitics stand in the second position, whereas weak ones show up in the next position to the right ${ }^{7}$. Old Russian, for one, attests two main triggers of split clitics. The first is when the initial part of the clause, hosting the first part of the enclitic chain, obtains certain predicative features. The second is attested when the weak reflexive enclitic cliticizes to the verb. Other constituents triggering split clitics are: (a) the fronted constituent which belongs to two coordinated clauses simultaneously; (b) embedded subordinate clause, finite and infinite; (c) vocatives, (d) wh-words, relatives and indefinite pronouns, subordinators [Zaliznjak 2008: 54-5].

It is important to mention here that in the cross-linguistic perspective clitic cluster split is not necessarily caused by the proclitic nature of the first constituent in the clause. Neither is the evidence for some constituents not counting as first for second position constituents limited to clitics. E.g., in Germanic verb second languages there are several constituents that systematically cause violation of the verb second order. In Scandinavian languages it consists of a set of focus adverbs like Swedish bara "only", nästan "nearly", till och med "even", helt enkelt "simply" [Holmberg 2015]:

$\begin{array}{clll}\text { (14) Han nesten } & \text { brølte hurra } \\ \text { he } & \text { almost } & \text { roared hooray [Holmber 2015: ex. 30b]. }\end{array}$

1.2. Is $m \bar{a} n$ Proclitic? The cross-linguistic evidence on cluster splits is well supported by the Hittite material. As far as $n u$ is concerned, it is clearly and unambiguously a proclitic, see the data summarized by [Kloekhorst 2014]. But all the rest of the constituents which [Kloekhorst 2014] attempted to reclassify as proclitics, are most likely not proclitics. Contra [Kloekhorst 2014: 612-3], apart from some extremely problematic and scanty data from 'poetic' texts ${ }^{8}$, for

\footnotetext{
${ }^{6}$ The example was provided by M. N. Belova.

7 This is not so in Bulgarian where $l i$ normally precedes the rest of clitics, but it shows up on the next host to the right if there is a negation marker in the clause.

8 " $m \bar{a} n$ does not seem to count as an accented word in the meter" [Kloekhorst 2014: 612] is characteristically unassertive.
} 
which see J. Korovina in [Sideltsev, Molina forthcoming], there is no independent evidence at all that mān "if/when" was ever unstressed". Moreover, all the evidence we possess points in the direction of $m \bar{a} n$ "if/when" being stressed. It is particularly probative if we apply to mān "if/when" the criteria employed by [Kloekhorst 2014: 601-2] to demonstrate that $n u$ was unstressed. The evidence pertaining to $m \bar{a} n$ "if/when" will then be dramatically different from that concerning $n u$. It goes as follows:

(a) $m \bar{a} n$ "if/when" is rarely, but consistently written at the end of a line, e.g., in the limited corpus of MH/MS letters (1300 clauses) there are 5 cases of line final mān, (7), out of 43 entries of $m \bar{a} n$ "if/when". If it was a proclitic, the writing would be unattested, as it is completely unattested with much more frequently occurring $n u$ :

(15) MH/MS (CTH 186) HKM 25 rev. 15-16

$15 .{ }^{10} n u=\check{s ̌ a ̆} \quad \operatorname{mān}$

CONN=LOC if

16. halki-ěš ar-ant-eš \#

crop-NOM.PL.C arrive-PRTC-NOM.PL.C

"If the crops have ripened, ..." (following [Hoffner 2009: 140-1]).

(16) $\mathrm{MH} / \mathrm{MS}$ (CTH 186) HKM 37 obv. 15-16

15. karū ar[ant-]eš \# $\boldsymbol{m a \overline { a } \boldsymbol { n } = w a = k a n}$

already arrive-PRTC-NOM.PL.C $\quad$ if=QUOT=LOC

16. antuhšāaltar parā h] $] \bar{u} d \bar{a} k$ nai-tti \#

Workforce out promptly dispatch-2sG.IMP

“... already ripe, if you promptly dispatch workers...” (following [Alp 1991: 188-9]; cf. [Hoffner 2009: 163, 166]).

(17) $\mathrm{MH} / \mathrm{MS}$ (CTH 186?) HKM 43 obv. 8'-10'

8'. n=ašta $\quad m \bar{a} n$

CONN=LOC when

9'. tuzzi-n $\check{s}[a] r \bar{a}[\ldots]$

army-ACC.SG.C up

10'. uwat-er \# ...

bring-3PL.PST

“And when they have brought the army up to ..., then" (following [Hoffner 2009: 169]).

(18) $\mathrm{MH} / \mathrm{MS}$ (CTH 186?) HKM 66 obv. 15-17

15. $n u=w a r=a s ̌ \quad m I m r a-L U ́-i-s ̌ \quad \mathrm{~m}$ Dula $[k] k[i]-\check{s}$

CONN=QUOT Imra-ziti (and?) Dulakki

16. tūri-ške- $d d u$ \# $\quad n u=w a=k a n \quad m \bar{a} n$

hitch-IMPF-3SG.IMP $\quad$ CONN=QUOT=LOC if

17. uit \# namma kuitki āšš-an \#

go-3SG.PST then something.NOM.SG.N remain-PRTC.NOM.SG.N

"Let Imra-ziti (and?) Dulakki hitch them up! And if it has happened that something is again left over" (following [Hoffner 2009: 220]).

(19) MH/MS (CTH 186?) HKM 66 obv. 22-24

22. widdu=wa DUMU m $\breve{S}[a] p a r t a a n d a$

go-3SG.IMP son Šaparta's in

\footnotetext{
${ }^{9}$ There is even less evidence for other members of the class.

${ }^{10}$ Line numbers in the original cuneiform tablets are being reproduced here.
} 
23. $w[e] m i y a-d d u \# \quad n=a \check{s} \quad[m] \bar{a} n$

find-3SG.IMP $\quad \mathrm{CONN}=$ he if

24. $k[a] r \bar{u} \quad$ pānza\# ...

already go.PRTC.NOM.SG.C

“Let him proceed to find Šaparta's son!” If he has already gone, ...” (following [Hoffner 2009: 220-1]).

(b) $m \bar{a} n$ "if/when" is never spelt together with the following word (i.e., there is always space between mān and the following phonological word);

(c) plene spellings of $m \bar{a} n$ "if/when" clearly dominate, both when it stands on its own and when it hosts enclitics;

(d) $m \bar{a} n$ "if/when" is occasionally in a clause internal position, which we interpret as clause second ${ }^{11}$, as in (20). The free position in the clause, identical to other non-proclitic subordinators, would be hard to reconcile with the putative proclitic character of mān.

(20) OH/OS (CTH 1.A) KBo 3.22 obv. 3

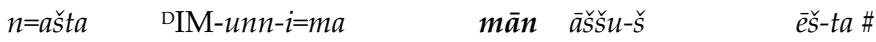

CONN=LOC Stormgod-DAT.SG=but when dear-NOM.SG.C be-3SG.PST

"And when he was dear to the Stormgod" (following [CHD L-N: 148]).

(21) OH-MH/MS (CTH 262) IBoT 1.36 rev. iii 55

nu LUGAL-u-š $m \bar{a} n$ GIšGIGIR wek-zi \#

CONN king-NOM.SG.C when chariot request-3SG.PRS

"When the king requests the chariot".

(22) $\mathrm{MH} / \mathrm{MS}$ (CTH 41.II.2) KUB 36.127 obv. 9'

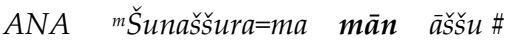

to Sunassura=but if good.NOM.SG.N

"If it suits Sunassura" (following [Fuscagni (ed.), hethiter.net/: CTH 41.II.2 (INTR 2011-08-24; Beckman 1996: 22]).

(23) NH/NS (CTH 69.A) KBo 19.70+ obv. i 52-53

kìdaš $\quad m \bar{a} n$ kui-š Š[A $M \bar{A} M \bar{I} T] I \#$

this.DAT.PL if which-NOM.SG.C of oath

"If there is someone of oath among these (men), ..." (following [Wilhelm \& Fuscagni (ed.), hethiter.net/: CTH 69 (TX 17.02.2014, TRde 17.02.2014; Beckman 1996: 80]).

Cf. the following lexically identical pair of examples where in (24) $m \bar{a}[n$ follows the first constituent ${ }^{12}$ whereas in (10) it is in its canonical clause initial position:

(24) $\mathrm{MH} / \mathrm{NS}$ (CTH 259.B) KUB 13.20 obv. i 13-15

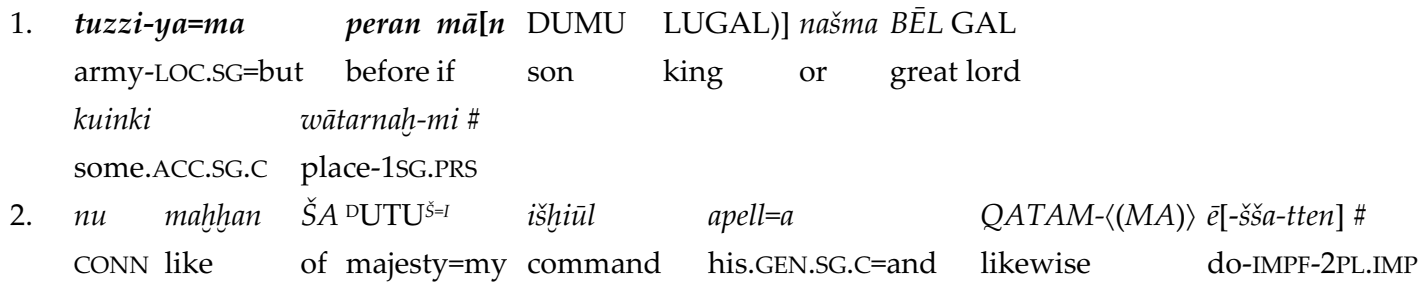

${ }^{11}$ We will provide a more detailed analysis elsewhere.

12 And not the first word, which is actually quite unusual for the second position in Hittite as normally the second position is determined after the first phonological word, as is done for - $m a$ in the same context. 


\section{3. $[n=a] n$ tuzzi-šs hümanza ištamaš- $(\check{s}) k e-d d u \#$ \\ CONN=him army-NOM.SG.C whole.NOM.SG.C listen-IMPF-3SG.IMP}

“(1) and if I place some [(prince)] or great lord in command of the army, (2) then just like the command of My Majesty [you must] ca[rry out] his (command) likew $\langle($ ise $)\rangle$ (3) [and] the whole army must obey [hi]m" (following [Miller 2013: 148-9]).

(25) MH/NS (CTH 259.B) KUB 13.20 obv. i 26-27

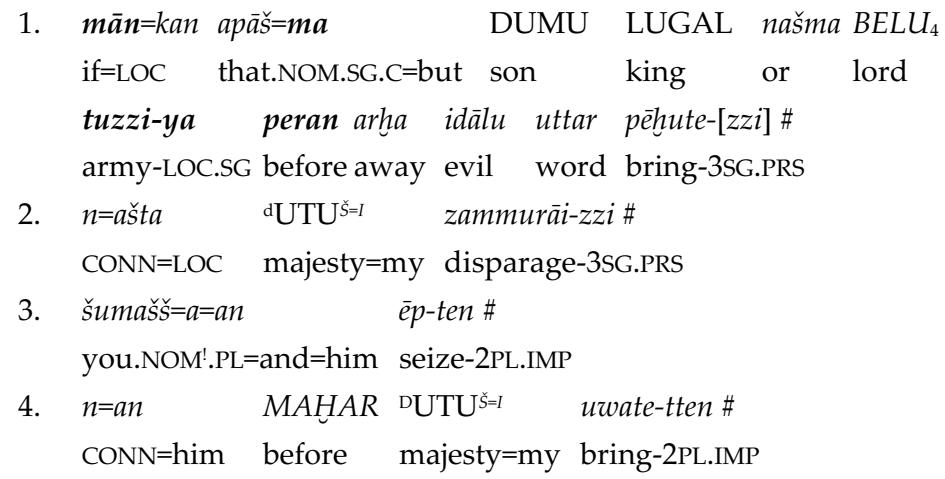

“(1) However, if that prince or great lord in charge of the army speak[s] a malevolent word (2) and he disparages My Majesty (3) then you must seize him (4) and you must bring him before My Majesty" (following [Miller 2013: 150-1]).

The following set of examples demonstrates the same variation between clause first and clause second position in very similar contexts from the same text:

(26) NH/NS (CTH 42.A) KBo 5.3+ rev. iii 12'-13'

\begin{tabular}{|c|c|c|c|c|}
\hline $\begin{array}{l}z i g=\underline{a}[(=s ̌ s ̌ i \\
\text { vou }=\text { but }=\text { him }\end{array}$ & $m \bar{a} n$ & $\begin{array}{l}p \bar{a} i-s ̌ s)] i \\
g_{O}-2 S_{G} \text { PRS }\end{array}$ & apūn & $\begin{array}{l}\text { EGIR-pa } \\
\text { back }\end{array}$ \\
\hline
\end{tabular}

"But if it so happens that you pass that word on to him" (following [G. Wilhelm (ed.), hethiter.net/: CTH 42 (INTR 2013-02-24)])

(27) NH/NS (CTH 42.A) KBo 5.3+ rev. iii 23'

$\underline{z i g}=[\underline{\underline{a}}=\check{s} m a] \breve{s}[=a] t \quad m \bar{a} n \quad p \bar{a} i-t t i \quad$ EGI[R-pa]mema-tti \#

you=but=them=it if go-2SG.PRS back say-2SG.PRS

"But if it so happens that you pass it on to them"

(28) NH/NS (CTH 42.A) KBo 5.3+ rev. iii 16'

$\begin{array}{lllllll}n u & m \bar{a} n & p \bar{a} i-[t t i] & \text { apūn } & \text { memiyan } & \text { apédani } & \text { EGIR-pa mema-tti \# } \\ \text { CONN } & \text { if } & \text { go-2SG.PRS } & \text { that.ACC.SG.C word.ACC.SG.C } & \text { that.DAT.SG.C } & \text { back } & \text { say-2sG.PRS }\end{array}$

"If it so happens that pass that word on to him"

(29) NH/NS (CTH 42.A) KBo 5.3+ rev. iii 20’

$\underline{z}[i g=] \underline{a} \quad m a \bar{n}$ apēdani KUR-e našma URU-r-i EGI[R-pa] mema-tti \#

you=but if that.DAT.SG. land.DAT.SG or city-DAT.SG back say-2SG.PRS

"But if you pass (it) on to that country or city"

Besides, mān "if/when" is usually spelt plene, which for Hittite does not imply synchronic accent, but in the majority of cases goes back to an accented vowel (see now [Kloekhorst 2014: 222]). Therefore, there is no positive evidence in favour of $m \bar{a} n$ being unstressed.

The evidence can also be supported by somewhat indirect considerations. There are NH/NS examples where mān "if/when" does host -ma [Kloekhorst 2014: 614; Sideltsev, Molina forthcoming]. In the logic of Kloekhorst, it is an unambiguous demonstration that mān "if/when" was 
stressed. [Kloekhorst 2014: 614] rather assesses them as analogical after māhhan "when". However, - $m a$ was hosted even more frequently by all the rest of the constituents that originally delayed -ma and for which there is no unambiguous evidence in favour of their being unstressed - again except clearly proclitic nu. These words (našma "or", namma "then", perfectivizing käša) are not obviously analogical after subordinators. Thus the diachronic development we see in Hittite is rather different from that outlined by [Kloekhorst 2014] and rather speaks in favour of the hypothesis that initially there was a set of words delaying - $m a$ irrespectively of being stressed. Then there was a diachronic reanalysis of the class: the proclitic $n u$ still delayed -ma whereas all the rest of the class which were originally stressed started hosting it, just like any stressed word in Hittite. So, the system that Kloekhorst proposes to account for the special behaviour of -ma paradoxically testifies against his own proposal.

\section{Relative Pronouns: Enclitic, Proclitic or Stressed?}

The second group of words which Kloekhorst assessed as proclitic is relative pronouns.

2.1. Hittite Relative Sentences: Basic Data. Here it is necessary to remind that traditionally, starting at least from [Held 1959], only relative pronouns in determinate relative clauses are described as being clause second. Relative pronouns in indeterminate relative clauses are clause initial or first if sentence connectives like $n u$ are available in a clause.

Determinate relative clauses is the traditional Hittitological term for referential relative clauses with the relative pronoun in the clause second position, which are illustrated by:

(30) OH-MH/MS (CTH 262) IBoT 1.36 obv. i 62

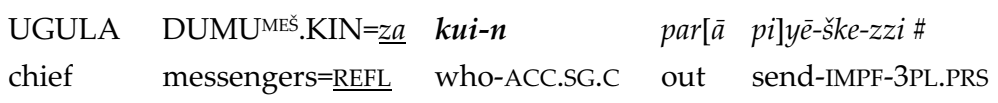

"The one whom the chief of the messengers di[sp]atches".

(31) OH-MH/MS (CTH 262) IBoT 1.36 obv. i 61-62

$\begin{array}{llllll}n u & 1 & \text { LúMEŠEDI } & \text { kui-š } & \text { šarkanti-n } & \text { widāi-zzi \# } \\ \text { CONN } & 1 & \text { bodyguard } & \text { who-NOM.SG.C } & \text { petitioner-ACC.SG.C } & \text { bring-3SG.PRS }\end{array}$

"A bodyguard who brings a petitioner, ...".

(32) OH-MH/MS (CTH 262) IBoT 1.36 obv. i 45

LÚMEŠED $[I=m] a$ kui-š ̌̌ehuna pai-zzi\#

bodyguard=but which-NOM.SG.C pee.INF go-3SG.PRS

"What bodygua[rd] goes to pee (without asking)".

(33) NH/NS (CTH 61.II.7.A) KBo 5.8 rev. iii 24-5

nu uni kuin 9 LIM ÉRINMEš mPitaggatalli-š $\quad$ uwate-t \#

CONN this who 9000 troops Pitagattalli-NOM.SG.C bring-3SG.PST

“That 9,000-man army which Pitagattalli led (joined battle with me)" (following [Goetze 1967: 158-9; Held 1957: 18; Hoffner, Melchert 2008: 158]).

Indeterminate relative clauses are generic with the relative pronoun in the first/initial position, as illustrated by (34):

(34) $\mathrm{MH} / \mathrm{NS}$ (CTH 259.B) KUB 13.20 obv. i 11

kui-š arha tarnu-mmaš=ma ÉRINMEšs-az \#

which-NOM.SG.C away release-INF.GEN.SG=but troops.NOM.SG.C

"Whatever troops are to be released, ..." (following [Miller 2013: 148-9]). 
Actually, the distinction between the second position of determinates and first/initial position of indeterminates is not absolute. On the basis of (35) [Yates 2014] proposed that indeterminate relative pronouns in Hittite can occupy the second position, just like determinate ones:

(35) NH/1NS (CTH 67) KBo 5.4 rev. 32-3

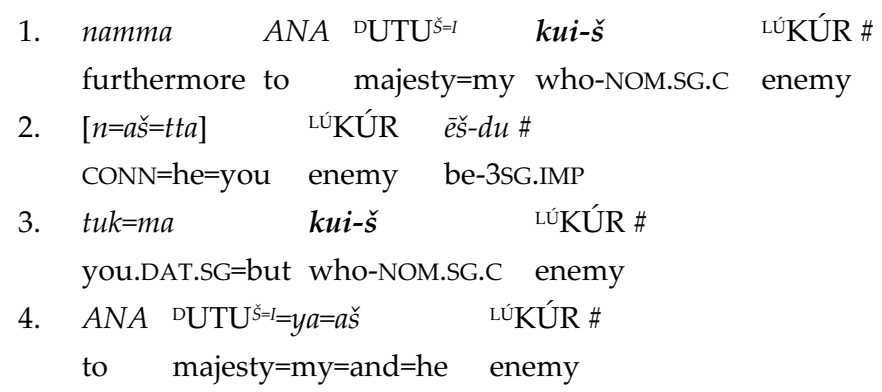

“(1) Furthermore, whoever is an enemy to His Majesty (2) shall be an enemy to you, (3) (while) whoever is an enemy to you (4) is also an enemy to His Majesty" (following [Yates 2014]).

However, as Yates observes (pers.comm.), there is just a handful of examples like (35) against thousands of first/initial position of indeterminate kui- and second position of determinate $k u i-$. Actually, the only example Yates quotes is ambiguous between second and preverbal position. [Becker 2014] went further and questioned the very validity of the difference between first and second position of relative pronouns. Whereas her criticism of the traditional assessment is certainly well grounded, it is far from being clear to what extent her own proposals ${ }^{13}$ capture the data.

2.2. Enclitic, Proclitic or Stressed? Now after the short excursus which is important for the following argument, we will return to the topic of the paper. [Kloekhorst 2014] proposes that relative pronouns are unstressed in order to explain that they do not host $-m a^{14}$. His logic is exactly the same as with mān "if": as $n u$ is unambiguously proclitic and it does not host -ma, it is sufficient for him to demonstrate that all other constituents which do not host -ma are proclitic, in order to account for the data. However, the explanation of the relative pronouns faces the same difficulties as that of mān "if": there is no unambiguous evidence in favour of relative pronouns being unstressed. As was said before, there are no cross-linguistic universals that clitic cluster split is caused exclusively by proclitics. What is more, even in comparison with mān "if" the proclitic hypothesis faces additional problems when it comes to the relative pronoun. If one assesses relative pronouns along the lines of Kloekhorst, one will have to assess clause initial/first relative pronouns as proclitics to explain the fact that they do not host $-m a$. At the same time, one will have to explain why in determinate relative clauses relative pronouns are in the second position. Kloekhorst does not consider determinate relative clauses, but [Huggard 2014] analyzes indefinite pronouns, which are also optionally clause second, and assesses them as unstressed and [Becker 2014] analyzes second position relative pronouns as unstressed. If one follows them, one will have to assume that clause second relative pronouns are enclitics to capture the fact that they are clause second whereas clause initial/first relative pronouns are proclitics. The solution is distinctly unwelcome.

As was observed above, for [Becker 2014] unstressed character of relative pronouns is one of the three factors that determine the position of relative pronouns in a clause. The main ar-

\footnotetext{
${ }^{13}$ Interplay of three factors - SOV word order, enclitic second position placement and topicalization.

${ }^{14}$ Delaying - $m a$ by relative pronouns happens much less regularly than by $n u$ or $m \bar{a} n$, but the frequency and consistency is of no direct relevance for us now.
} 
gument against this analysis is the following: the position of a constituent in a clause cannot be simultaneously determined in the same uses ${ }^{15}$ in some cases by information structure and in some cases by the fact that it is unstressed. In Becker's account relative pronouns occupy the second position in the clause in $66 \%$ of cases. The statistics is interpreted by Becker to the effect that relative pronouns are enclitics [Becker 2014: 101-3]. However, prototypical enclitics do not demonstrate $2 / 3$ tendency to be in the second position, they are in the second position. Statistics is in this case convincing only if it is about $90 \%$ and does not represent a tendency.

The scenario by which unstressed forms could obtain stress was offered by [Huggard $2014]^{16}$ who put it forward for indefinite pronouns. For him a form may acquire stress and consequently can occur in the first position if it is topicalized. However, the account works only for some cases of first/initial position of relative pronouns. There is indeed contrastive topicalization accompanied by -ma as, e.g., in Becker's ex. (83). But with some other clause first/initial relative pronouns there is no contrastive topicalization at all, as in, Becker's exx. (84), (97) and many others.

What is more, as was exposed in the previous section, indefinite clause initial kui- delays $-m a$ in a number of cases, i.e. $-m a$ is cliticized to the word that follows kui-, and not to kui- itself ${ }^{17}$ ! Even if clause first/initial indefinite pronouns were systematically topicalized and hereby received stress, the fact that they delayed the topicalizing particle is extremely hard to understand.

Besides, and probably more important, as was demonstrated by [Huggard 2011], relative pronouns as well as relative phrases are also preverbal, both in determinate and indeterminate relative clauses ${ }^{18}$ :

${ }^{15}$ We leave apart partitive use and focus only on properly relative function.

${ }^{16}$ Becker does not put forward the explanation. It looks like for her the same pronoun can be both stressed and unstressed depending on the factors she did not reveal.

${ }^{17}$ As different from, e.g., $m \bar{a} n$, the delay is always optional.

${ }^{18}$ The same three positions (preverbal, second and first/initial) are attested for subordinators māhhan "when, as" and kuit "as". See above for the preverbal and second positions. The first/initial position is illustrated by:

(i) $\mathrm{OH}-\mathrm{MH} / \mathrm{MS}$ (CTH 262) IBoT 1.36 obv. ii 29

$n u=\check{s ̌ s} i=k a n \quad m a \bar{h}[h a] n$ Lú.MEšMEŠEDI DUMUMEš É.GAL=ya handā-nta \#

CONN=him=LOC when bodyguards servants palace=and be.aligned-3PL.PRS

"When bodyguards are aligned with palace servants, ..."

(j) MH/NS (CTH 259.B) KUB 13.20 obv. i 10

mahhan=ma LÚKÚRak-i \#

when=but enemydie-3SG.PRS

"However, as soon as the enemy has been vanquished, ...", following [Miller 2013: 148-9].

(k) MH/MS (CTH 186) HKM 17 rev. 36

$n=a s ̌=s ̌ i \quad$ kuit NU.GÁL kuiški \#

$\mathrm{CONN}=\mathrm{he}=$ him because no someone.NOM.SG.C

"Because there is no one for him", cf. [Hoffner 2009: 125].

(1) MH/MS (CTH 186) HKM 55 rev. 33-34

man=kan kuit mahhan anda\#

OPT $=$ LOC how how in

"How it is there", following [Hoffner 2009: 201].

In this last example optative man is likely to behave like conditional mān and thus not constitute the first position. The position is actually dominating for mähhan "when, as", see [CHD L-N sub mähhan], and very sporadic for kuit "as". 
(35) NH/OS (CTH 292.II.a.B) KBo 6.26 rev. iii 15 (§ 185)

$2 \mathrm{GU}_{4}$ GAL UZU=ŠUNU $k u i-s ̌ \quad w a ̄ s ̌-i ~ \#$

2 cattle big meat=their who-NOM.SG.C buy-3SG.PRS

"Whoever buys the meat of 2 fullgrown cattle" (following [Hoffner 1997: 147]).

(36) MH/MS (CTH 190) HKM 71 rev. 24-26

$k \bar{a} s ̌ a=k a n$ tuppi kuedani UD-t-i parā ne-ḩhun \#

PRF=LOC this tablet which day-LOC.SG out send-1SG.PST

"On the day that I have dispatched this tablet" (following [Hoffner 2009: 228]).

How do we assess the preverbal relative pronouns - as enclitic or as proclitic? Needless to say, none of the unambiguously unstressed constituents (either enclitics or proclitics) in Hittite have an optional, but systematic preverbal position. See the discussion on indefinite pronouns below where it is shown that the pronouns which are unambiguously unstressed in Latin and Greek never attest systematic preverbal position.

2.3. Now we will present the synchronic Hittite data against both the enclitic and proclitic character of relative pronouns. Here, just like in the section concerning $m \bar{a} n$ "if", we arrange the material along the lines in the cuneiform tablet:

(37) MH/MS (CTH 186) HKM 2 obv. 4-5

4. $\quad \check{S} A \quad$ ANŠE.KUR.RA ${ }^{\mathrm{HI} . \mathrm{A}}=\underline{m u}$

of horses=me

5. kuit uttar hatrāe-š \#

which matter write-2SG.PST

"Concerning the matter of chariotry about which you wrote to me, ..." (following [Hoffner 2009: 98]).

The example clearly shows the difference between Wackernagel enclitics like the pronoun $=m u$ " $m e$ " and relative pronouns: here the unambiguous enclitic directly follows its host in the same line whereas the relative pronoun kuit "which" starts a new line!

The following example does the same for yet another enclitic vs relative pronoun:

(38) MH/MS (CTH 186) HKM 2 obv. 10-11

10. ŠA ŠEŠ $\quad{ }^{H} H i m u$-DINGIR ${ }^{\text {LIM }}=\underline{m a}$

of brother Himmuili=but

11. kuit uttar hatrāe-š \#

which matter write-2SG.PST

“Concerning the matter of Himmuili's brother about which you wrote, ...” (following [Hoffner 2009: 99]).

This example likewise clearly shows the difference between the two second position constituents (which are non-Wackernagel, see [Sideltsev, Molina forthcoming]) - prototypical enclitic =ma and relative pronoun kuit "which": the unambiguous enclitic directly follows its host in the same line, the relative pronoun starts a new line.

The situation seems analogous to the one in Homer Greek, where the relative pronoun (although derived from the other PIE root ${ }^{*} y o-$ ) can easily start a new line, host enclitic constituents and is never regarded as a proclitic or enclitic form:

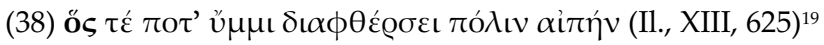

ös $\tau \dot{\varepsilon} \quad \pi \mathrm{o} \tau^{\prime}$

who.REL.PRON.NOM.SG.M and.ENCL.CONJ someday.ENCL.INDEF.PRON

${ }^{19}$ In the middle of the verse, starting a new sentence; $\tau \dot{\varepsilon}$ also is enclitic having acute due to attraction. 


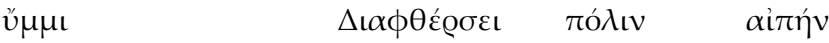

for us-PERS.PRON.DAT.PL destroy.FUT.3SG city.ACC.SG.F lofty.ACC.SG.F

"and who someday will destroy us [our] lofty city";

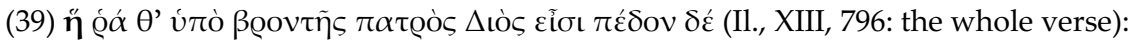

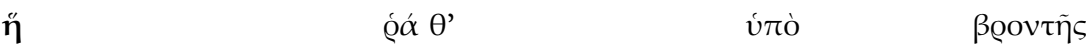

which.REL.PRON.NOM.SG.F really.PRAGM.PART.ENCL and.ENCL.CONJ with.thunder.GEN.SG.F

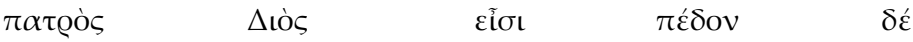

father.GEN.SG.M Zeus.GEN.SG.M goes.PRS.3SG valley.ACC.SG and-ENCL.PART

"and [it was the storm] which with thunder of father Zeus goes to the valley".

In the latter example it is notable that $\eta$ (which-NOM.SG.F) is followed by the pragmatic

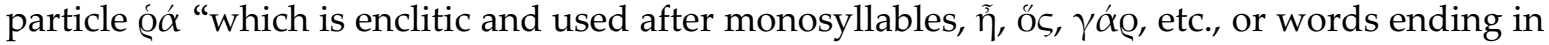

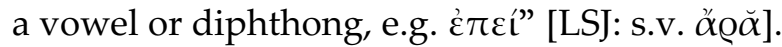

The same holds good for the two additional Hittite cases which come from the same context:

(40) MH/MS (CTH 186) HKM 9 obv. 3-7

3. 13 LÚ.MEšpítteand-uš=kan

13 fugitives-ACC.PL.C=LOC

4. kuit parā nai-tta

what out send-2sG.PST

5. $n=a$ š uwater \# $\S$

CONN=them bring.3PL.PST

6. $\breve{S} A \quad$ ANŠE.KUR.RA ${ }^{\mathrm{HI} . \mathrm{A}=}=\underline{m a=m u}$

of horses=but=me

7. kuit uttar hatrāe-š \#

what word write-2SG.PST

which matterwrite-2SG.PST

"Concerning the fact that you dispatched (to me) 13 (apprehended) fugitives: They have brought them here. $\S$ Which word you wrote to me about the horse troops (I received your message)" (following [Hoffner 2009: 113]).

(41) MH/MS (CTH 186) HKM 36 l.e. 29-30

29. $\breve{S} A$ ÉRINMEš URUIšhūpitta=ma=mu

of troops Ishupitta=but=me

30. kuit huttar hatēe-[̌̌ \#

what.ACC.SG.N matter.ACC.SG.N write-2SG.PST

"Concerning the matter of the troops of the town Išhupitta which you wrote to me" (following [Hoffner 2009: 132-3]).

Naturally, the examples can be interpreted ad hoc as testifying for the proclitic character of preverbal kui- "which". However, unambiguously second position of the relative pronoun is attested by the following examples. The pronouns in these examples are clearly not enclitic as they are in the next line from the first position constituent:

(42) MH/MS (CTH 186) HKM 10 obv. 20-21

$\begin{array}{rll}20 . & \ldots n u \quad \text { LÚmEš } & \text { URU Gašga } \\ & \text { CONN people } & \text { Gasga }\end{array}$

21. kui-ēs takšul-i iya-ndari \#

who-NOM.PL.C peace-DAT.SG.C go-3PL.PRS.MED

“The Kaškaean men who are coming to make peace, ...” (following [Hoffner 2009: 113]). 
(43) MH/MS (CTH 186) HKM 31 obv. 8-10

8. $\check{S} A \quad$ URU Gašaša $=m a=m u$

of Gasasa=but=me

9. kuit $\breve{A} A$ GIŠGEŠTIN uttar

what of vineyard matter

10. hatrā-eš \# ...

write-2SG.PST

"Concerning the matter of the vineyards of (the city) Kašaša about which you wrote to me" (following [Hoffner 2009: 156]).

(44) $\mathrm{MH} / \mathrm{MS}$ (CTH 186) HKM 31 obv. 13-15

13. Š É DUTU ${ }^{\check{S}=I}=m a=m u$ of house Majesty=My=but=me

14. kuit Lúmaniyahhiy-aš what administrative.district-GEN.SG.C

15. EN-aš uttar hatrā-eš \# ...

lord-GEN.SG.C matter.ACC.SG.N write-2SG.PST

"Concerning the matter of the district lord of the house of My Majesty about which you wrote" (following [Hoffner 2009: 156]).

(45) MH/MS (CTH 190) HKM 52 rev. 42-1.e.3

42. $\breve{S} A$ ANŠE.KUR.RA GIšGIGIR=ya=mu

of horse chariot=and=me

43. kuit huttar hä-eš \#

which.ACC.SG.N matter.ACC.SG.N write-2SG.PRS

"Concerning the matter of the horse(s) and chariot which you wrote" (following [Hoffner 2009: 195]).

(46) $\mathrm{MH} / \mathrm{MS}$ (CTH 186) HKM 54 obv. 18-20

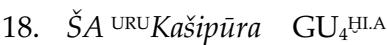

of Kašipūra cattle

19. kue A.ŠÀterippi

which.ACC.PL.N field.ACC.PL.N

20. A.Š[À]terippiya- $t$ \# ...

plow-2SG.PRS

"Regarding the fields that you plowed with the cattle of Kašipūra" (following [Hoffner 2009: 199]).

The next examples are against the enclitic character of the unambiguously preverbal relative pronouns:

(47) MH/MS (CTH 186) HKM 21 obv. 6-7

6. EGIR!-an=mu kappūwar

back=me number.ACC.SG.N

7. [ku]it hatrāe-š \# ...

what.ACC.SG.N write-2SG.PST

“The number (of workers) which you wrote to me” (following [Hoffner 2009: 132-3]).

(48) MH/MS (CTH 188) HKM 48 obv. 18-19

18. $n u=k a n \quad k \bar{e} \quad$ MUŠENHI.A

CONN=LOC these birds

19. kue-dani KASKAL-š-i anda

which-LOC.SG road-LOC.SG on 
20. ร̌anh-weni \# ...

seek-1PL.PRS

"In which direction (literally: on which road) we should seek these birds" (following [Hoffner 2009: 183]).

(49) $\mathrm{MH} / \mathrm{MS}$ (CTH 186) HKM 54 obv. 4-5

4. $\breve{S}$ A NUMUNHI.A=mu uttar kuit

of seeds=me matter.ACC.SG.N which. ACC.SG.N

5. ḩatrā-ě̌ \#

write-2SG.PRS

“Concerning what you wrote me about seed" (following [Hoffner 2009: 199]).

The following example is against the proclitic nature of the preverbal subordinator kuit "as", homonymous with the ACC.SG.N form of the relative pronoun:

(50) MH/MS (CTH 186) HKM 17 obv. 28-29

28. URUKapapahšuwaš mekki kuit

Kapapahsuwa much as

29. [paḩһ̌̌̌n]uwanza \#...

protected

"Since Kapapahsuwa is well protected, ..." (following [Hoffner 2009: 124]).

The following examples are against the enclitic character of the second position subordinator kuit "as":

(51) $\mathrm{MH} / \mathrm{MS}$ (CTH 186) HKM 10 obv. 28-29

28. ... nu karū

CONN already

29. kuit DINGIR ${ }^{\mathrm{MES}}[i] \operatorname{mmanx}[\ldots]$ \#

as gods $\mathrm{x}$

"Just because the gods already [...], ..." (following [Hoffner 2009: 113]).

(52) $\mathrm{MH} / \mathrm{MS}$ (CTH 186) HKM 44 1.e.2-rev. 5

2. $[a] n d a=m a=k a n \quad k \bar{a}\left[\check{s}(m) a^{2}\right]$

furthermore=but=LOC PERF

3. ${ }^{\mathrm{m}}$ Marakui-n

Marakui-ACC.SG.C

4. kuit LÚQARTAP $\langle P U\rangle$

since charioteer

5. parā ne-hhun \#

outsend-1SG.PST

"Since I have just dispatched (to you) Marakui, the charioteer, ..." (following [Hoffner 2009: 170-1]).

The following example is particularly telling against both enclitic and proclitic nature of the subordinator kuit "as". Here it follows the nominal part of the predicate and is in the next line from it. Thus it is the only part of the previous clause which is in a separate line from all the rest of the clause:

(53) MH/MS (CTH 186) HKM 18 1.e.2-3

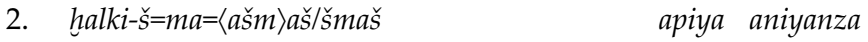

grain-NOM.SG.C=but=them/you/them/you there done.NOM.SG.C

3. kuit\# $\#$ E EGIR-an tiya-tten \#

because CONN back step-2PL.IMP

"Because grain has been sown/cultivated there or them/you, get busy" (following [Hoffner 2009: 128]). 
It is important that the examples are not isolated. They come from a very limited corpus of $\mathrm{MH} / \mathrm{MS}$ letters and instructions. A broader corpus brings more examples. Thus, synchronic Hittite data are identical to the data from Narrow IE languages exemplified here by Greek and give no reason to assume some special enclitic or proclitic character of relative pronouns in Hittite. Becker [2014] attempted to provide the comparative IE evidence supporting her claim that Hittite enclitic relative pronouns go back to proto-IE situation, but all the evidence she produced concerns indefinite pronouns and will be reviewed in the following section.

\section{Indefinite Pronouns - Enclitics or Lexically Unstressed?}

The third category that has been suggested to be unstressed is indefinite pronouns. Detailed arguments in favour of indefinite pronouns being lexically unstressed have been provided by [Huggard 2014].

Just like relative pronouns, indefinite pronouns occupy three positions in a clause (see for more detail [Huggard 2014; Sideltsev 2014a, 2014b]): they are preverbal, second position, and they can also be, albeit extremely seldom, clause initial/first. The difference between relative and indefinite pronouns is statistical: indefinite pronouns are preverbal in the absolute majority of cases, much more seldom in the second position and extremely rarely in the first/initial position.

Preverbal position:

(54) OH/OS (CTH 291.I.a.A) KBo 6.2 rev. iv 19 (§ 83)

$\begin{array}{llll}\text { [t]akku ŠAH } & \text { arnuand-an } & \text { kuiški } & \text { taye-zzi \# } \\ \text { if } \quad \text { sow } & \text { pregnant-ACC.SG.C } & \text { somebody.NOM.SG.C } & \text { steal-3sG.PRS } \\ \text { "If anyone steals a pregnant sow, ..." (following [Hoffner 1997: 86-87]). }\end{array}$

(55) MH/MS (CTH 190) HKM 66 obv. 16-17

$n u=w a=k a n \quad m a \bar{n}$ ui-t namma kuitki äššan \#

CONN=QUOT=LOC if come-3SG.PST again something leave.PRTC.NOM.SG.N

"And if it has happened that something is again left over, ..." (following [Hoffner 2009: 220]).

Particularly intriguing in this respect are the examples where only the indefinite pronoun is preverbal whereas the head NP is not preverbal:

(56) OH/OS (CTH 291.I.a.A) KBo 6.2 obv. i 39 (§ 19b)

[(takku URU)]Hattuš-i=pat LÚ URUHatti LÚ URULū̄-n kuiški tāye-zzi \#

if Hattusa-LOC.SG=EMPH man Hatti man Luwian-ACC.SG.C somebody.NOM.SG.C steal-3SG.PRS

"If a Hittite abducts a Luwian man in the land of Hatti itself, ..." (following [Hoffner 1997: 31]).

(57) $\mathrm{MH} / \mathrm{NS}$ (252.A) KUB 13.8 obv. 11-12

mān $\underline{\text { ŠA É.NA }} 4=m a \quad$ hinqan-aš $\quad \underline{\underline{w a s ̌ t u l}}$

if of stone.house=but death-GEN.SG.C crime.ACC.SG.N

kuiški waštai \#

anyone.NOM.SG.C sin.3SG.PRS

"If, however, anyone from the royal funerary structure commits a capital crime, ..." (following [Miller 2013: 210-1]).

(58) $\mathrm{MH} / \mathrm{NS}$ (CTH 264.A) KUB 13.4 rev. iv 61-62

$\begin{array}{lllll}m \bar{a} n=m a=k a n & \check{S} \mathrm{~A} & \text { KASKAL-NI } & \text { LÚSIPAD.GU }_{4} & \underline{n a s ̌ m a} \\ \text { if=but=LOC } & \text { middle } & \text { way } & \text { cowherd } & \text { or }\end{array}$




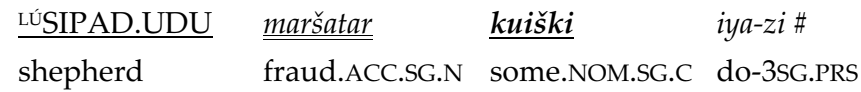

"But if along the way some cowherd or shepherd commits $\underline{\underline{\text { fraud}}}, . .$. " (following [Miller 2013: 264-5]).

(59) NH/NS (CTH 577) KBo 2.2 obv. i 41-46

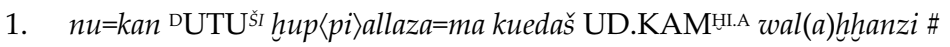

2. peran=kan kuedani memiyani lahlah̆hešgaueni \#

3. $n=a n=k a n$ tapašša-š apiya kuiški anda wemiyazi \#

CONN=him=LOC fever-NOM.SG.C then some-NOM.SG.C in find-3sG.PRS

“(1) Or on which days they beat His Majesty with the huppialla, - (2) for which matter we keep worrying in advance -, (3) will some fever befall him then?” (following [Goedegebuure 2014: 405]).

(60) NH/NS (CTH 106.A.1) Bo 86/299 obv. ii 99-100

$m a \bar{n}=m a \quad \underline{D U M U}=K A \quad$ DUMU.DUMU=KA $k a t t a^{20}$ wašta-i=ya kuiški \#

if=but son=your grandson=your later sin-3SG.PRS=and someone.NOM.SG.C

"But if any son or grandson of yours later commits an offense, ..."21.

Second position:

(61) NH/NS (CTH 62.II.A) KBo 5.9+ rev. iii 23-24

našma mān KUR ${ }^{\text {тuм }}$ kuitki zaḩ̧iya-za LUGAL KUR URUHatti anda hatkišnu-zzi\#

or if land some.ACC.SG.N battle-ABL king land Hatti in besiege-3SG.PRS

"Or if the King of Hatti besieges some land in battle" (following [del Monte 1986: 170-1; Beckman 1996: 58]).

Huggard [2014] explains the difference between the preverbal and second position by the fact that preverbal indefinite pronouns are existential whereas second position indefinite pronouns are topicalized or at least presupposed. Sideltsev will show elsewhere that the hypothesis works only for the minor part of the data and cannot be upheld ${ }^{22}$.

First/initial position:

(62) NH/NS (CTH 255.2.A) KBo 26.1+ rev. iii 16

nu=za kui-t GIM-an kiš-ari \#

CONN=REFL which-NOM.SG.N when happen-3SG.PRS.MED

"If something happens ..." (following [Miller 2013: 300-1]).

(63) NH/NS (CTH 266) KBo 16.54+ rev. iii? 16'

man $(a)=s ̌ a n ~ k u w a p i \quad$ URU-r-iya EGIR-pa [ar-ti] \#

if/IRR=LOC when city-LOC.SG back come-2SG.PRS

"Should you at some point re[turn] to the city, ..." (following [Miller 2013: 268-9]).

(64) $\mathrm{MH} / \mathrm{NS}$ (CTH 258.2) KUB 13.7 obv. 9

$m \bar{a} n=a n=z a \quad k u w a p i=m a \quad$ appezzian LUGAL-u-š EGIR-an kappūēe-zzi \#

if=him=REFL when=but later king-NOM.SG.C back count-3sG.PRS

"If, however, the king reassesses him (i.e., his case) at some point" (following [Miller 2013: 140-1]).

${ }^{20}$ Contra [Garrett 1990: 79; Salisbury 2005: 85], katta is not here a preverb, rather an adverb with the meaning "later", which follows from its meaning which is identical to the unambiguous adverb [Salisbury 2005: 83-5]. It is true that katta is not normally clause internal in this meaning, but it is also very obvious that the aberrant syntactic behaviour should tip the balance in favour of katta being an adverb.

${ }^{21}$ Following [Otten 1988: 20-21; Beckman 1996: 113]. The example also involves the non-canonical clause internal verb position.

${ }^{22}$ Besides, the theory is obviously unapplicable to the subordinators which attest the same distribution. 
(65) OH-MH/MS (CTH 262) IBoT 1.36 obv. i 69-71
1. LÚ.MEšMEŠEDI=ma Éarkiw-
bodyguards=but passageway-LOC.SG alongside right-ABL stand-3PL.PRS

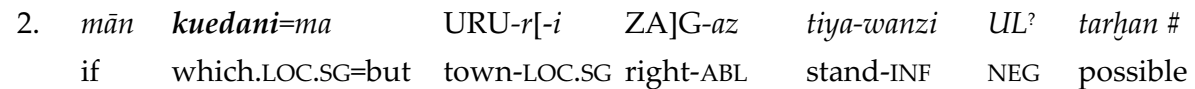

"(1) but the bodyguards stand to the right alongside the passageway. (2) If, however, in some town standing to the [rig]ht is not possible, (then they stand on the left)" (following [Miller 2013: 106-9]).

We suppose it is not incidental that the absolute majority of indefinite pronouns in the first position are identical to relative pronouns or subordinators, i.e., they do not attest the enclitic $=k i$ and are attested in post-OH time in conditional clauses. It is important that $k u e d a n i$ is not topicalized in cl. 2 of the last example of (65), -ma is here contrastive with sentential scope. The only case in our corpus where the genuine indefinite pronoun is in the first position is:

(66) MH/MS (CTH 199) ABoT 1.65 rev. 5'-7'

\begin{tabular}{|c|c|c|c|}
\hline $\operatorname{mam}=\operatorname{man}=z a=k a n$ & kuiški & É-er tamai-š & arnu- $t \#$ \\
\hline
\end{tabular}

"If someone else had relocated (your) household/ family, (would you not become upset?)" (following [CHD L-N: 141; Hoffner 2009: 244; Hoffner, Melchert 2008: 422]).

It is not contrastively topicalized either.

But it is the following long context which is particularly revealing as the only indefinite pronoun in the first position in a clause is actually relative in form (cl. 3, where [Miller 2013] reads $k u i n\langle k i\rangle)$. All the rest of numerous indefinite pronouns are either preverbal or in the second position:

(67) NH/NS (CTH 255.1.A) KUB $21.42+$ rev. iv 22-31

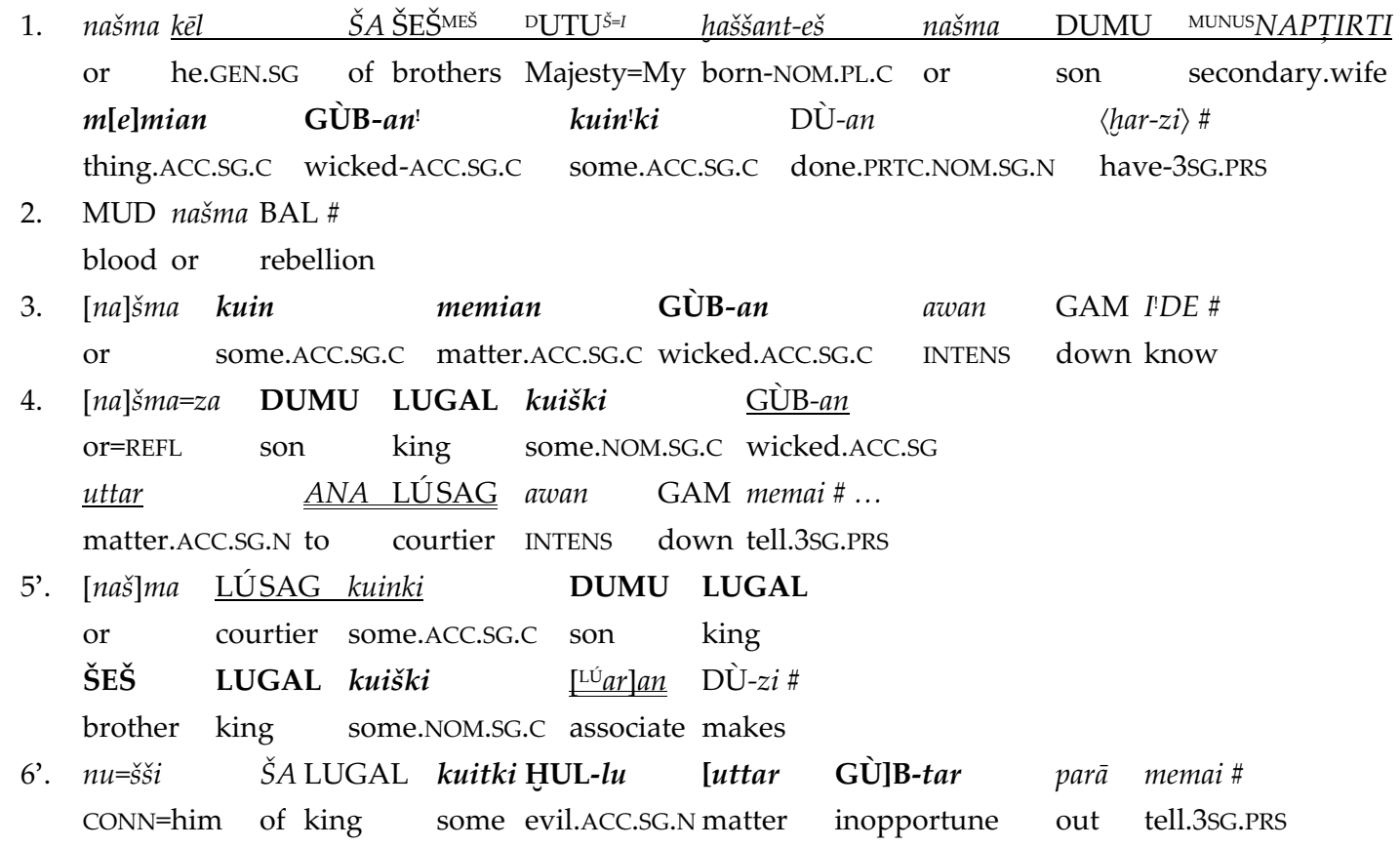

"(1) Or (if) the full brothers of My Majesty and a son of a secondary wife has 〈done〉 some wicked thing, (2) (e.g.,) blood(shed) or rebellion (3) or he has foreknowledge of some wicked matter; (4) [o]r some prince divulges a wicked $\underline{\text { matter to a courtier, }}$ (or he has also already [to]ld you, but you do not report it to the king;) (5') [o]r some prince (or) brother of the king makes some courtier (his) [ass]ociate, (6') and he divulges to him some evil, [inopp]ortune [matter] regarding the king, (but does not report it to the king: under the oath)" (following [Miller 2013: 290-1]). 
Huggard proposes that indefinite pronouns are unstressed, or, rather, that they are lexically unstressed. Lexical unstressability for him is different from the unstressability of clitics as lexically unstressed words can bear topic stress as in:

(68) NH/NS (CTH 40.IV.1.A) KBo 5.6 obv. i 21

1. $n u=k a n$ kui-t kuenn-ir \#

CONN=LOC some-ACC.SG.N kill-3PL.PST

2. kuit $=\underline{m a}=z a=k a n \quad$ anda épp-ir \#

some-ACC.SG.N=but=REFL=LOC in seize-3PL.PST

“(1) And some they slew, (2) but some they seized.” (Borrowed from [Huggard 2014: ex. (15)]).

Here it must immediately be observed that no unambiguous indefinite pronoun ever hosts - $m a$ in our corpus ${ }^{23}$. As follows from above and from the data of Huggard [2014], all the cases where indefinite pronouns host - $m a$ actually involve relative pronouns or subordinators functioning as indefinite pronouns after $m \bar{a} n$ "if". Alternatively, the relative pronouns/ subordinators have a distributive function, as in Huggard's example above.

As for unstressability in the second position, cross-linguistically the second position of a constituent in a clause is not tied in to unstressability - e.g., verb in the second position is not unstressed in Germanic languages [Bošković 2001]. The same holds good for second position relative pronouns and subordinators in Kashmiri [Munshi, Bhatt 2009]. I.e. if a word stands in 2P, the lack of stress does not immediately follows.

Moreover, indefinite pronouns in Hittite are productively built from relative pronouns/subordinators with the help of indefinite enclitic - $k i$ [Hoffner, Melchert 2009]. This formant is not a suffix as it cliticizes to the inflected form of the pronoun bearing case, number and gender affixes. It clearly produces the impression of an enclitic. What is important is that the enclitic is not a second position enclitic. All other non-2P (or at least not necessarily $2 \mathrm{P}$ ) enclitics like -pat cliticize only to stressed words. This is admittedly a very indirect argument, but quite a sound one ${ }^{24}$.

One of the arguments of [Huggard 2014] and Becker [2014: 100-1] in favour of indefinite pronouns being unstressed is that other Indo-European languages attest unstressed indefinite pronouns and thus the Hittite system which they construe as unstressed should be diachronically equated with the Narrow IE one.

The Narrow IE system ${ }^{25}$ is best preserved in Latin and Greek where wh-words are stressed in their primary function and unstressed when they function as indefinite pronouns (see now [Haug forthcoming]).

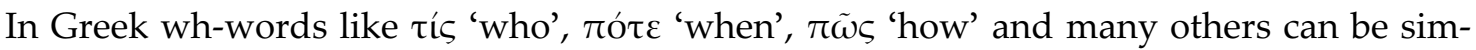
ply converted into indefinite pronouns by dropping their phonological accent. See, e.g., the following examples from Greek (Homer, Ilias):

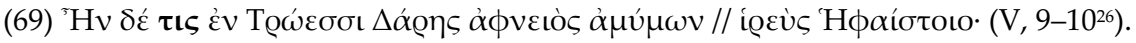

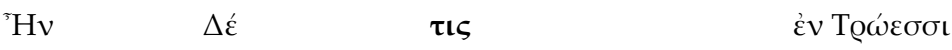

be. IMPF.3.SG but-ENCL.PART some.ENCL.PRON.NOM.M among Trojans.DAT.PL.

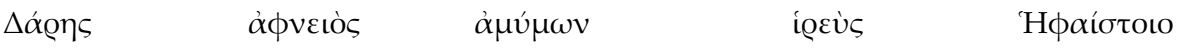

Dares.NOM.SG. rich.NOM.SG.M blameless.NOM.SG.M priest.NOM.SG Hephaestus.GEN.SG.

"But there was among Trojans one (so-called) Dares, a rich and blameless man, a priest of Hephaestus".

${ }^{23}$ Here the broader corpus of diplomatic texts, oracles, dreams and prayers was studied.

${ }^{24}$ We thank A.Kassian for the idea.

${ }^{25}$ See for further examples [Haug forthcoming; Becker 2014; Huggard 2014], all with references.

${ }^{26}$ In a stable epic expression before proclitic; cf. 10, 314. 


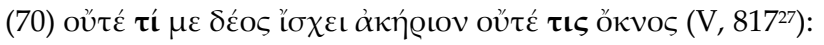

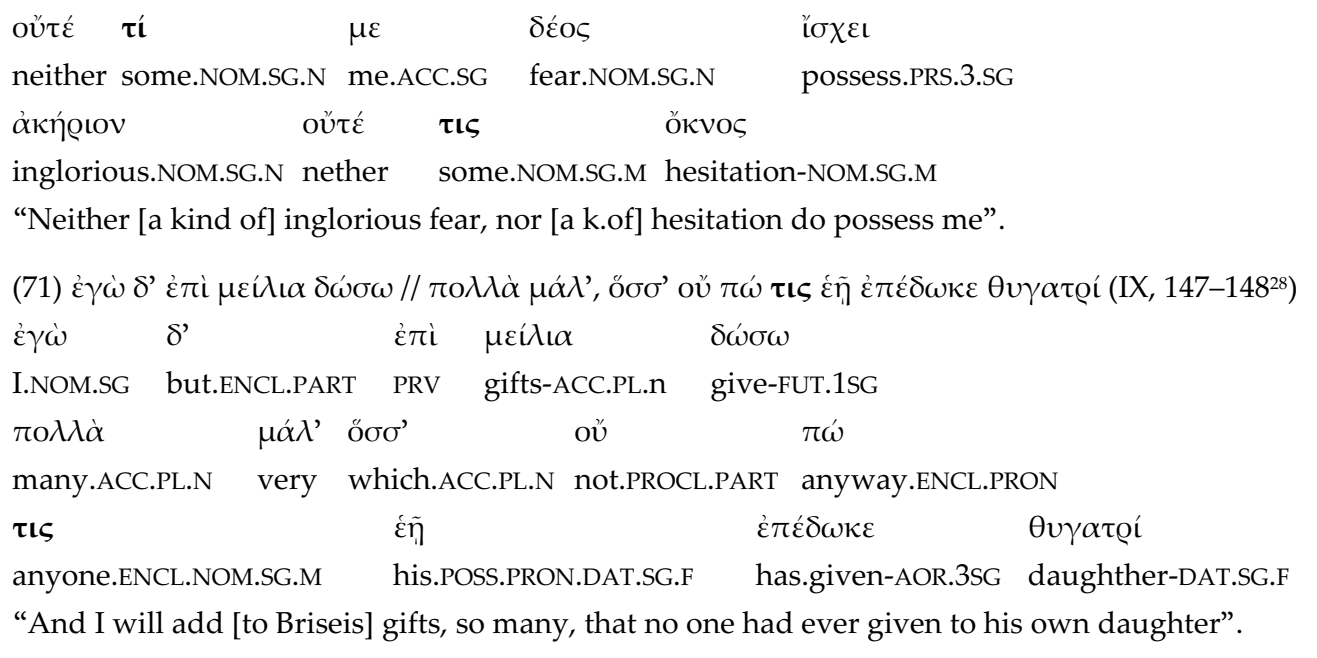

Main evidence in favour of $w h$-words functioning as indefinite pronouns being unstressed in Greek comes from ancient grammarians and is supported by the well-known facts of the history of Greek writing ${ }^{29}$. Some particular cases could be determined on bases of Greek common accent and phonological ${ }^{30}$ rules.

In Latin we do not have such strong arguments coming from the writing tradition, but the system is clear enough:

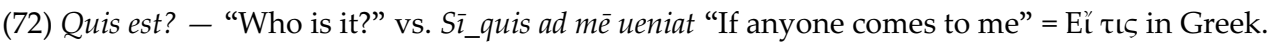

Wh-words function as indefinite pronouns in Latin normally after $s \bar{l}, n \bar{e}$ and thus are in the second position as dramatically different from wh-words in their original function which are clause initial. It is notable that dropping accent in Latin is not the most preferable way for producing indefinite pronouns (they usually are derived from wh-words by old enclitic particles: quis-quam, quis-piam etc. 'anyone'), but in some clear circumstances (e.g. after $s \bar{l}, n \bar{e}$ ) this way becomes favorable. In the whole PHI-5 Latin corpus one can find only 33 entries for sīquisquam and only 2 archaic cases for sì_quispiam (in Plautus), whereas there are thousands of entries for $s \bar{l}$ qquis. It could be regarded as indirect evidence for the fact that an indefinite pronoun, standing in the enclitic-host position, can hardly host an enclitic-like particle (-quam or -piam) itself. Also it is notable that quisquam (instead of indefinite quis) in several cases, presumably rhetorical questions, can start the sentence and even host some other enclitic particles (like interrogative -ne) behaving as "monolithic" compound rather than a set of separate enclitic pieces: Quisquam istuc negat (Cic. N.D. III, 70)? - "How could anyone deny it?”. Quisquam-ne... in lite cantat (Quint. XI, 3, 59) - "Can anyone sing in the court"? The indefinite pronoun quĩdam (also of enclitic origin: cf. fem. quae-dam and neut. quod-dam) can occupy the first position of the phrase much more easily.

${ }^{27}$ In the negative enclitic construction; $\tau i$ has an acute accent of phrase origin which is due to the enclitic attraction. For rules see [Belov 2015: $260 \mathrm{ff}$.].

${ }^{28}$ Same to (70), but before a possessive pronoun with uncertain prosodic status. Acute accents on ov́ and $\pi \dot{\omega}$ are due to the enclitic attraction.

${ }^{29}$ See [Tronsky 1962; Probert 2006]. Some uncertain cases, especially concerning enclitics and enclinomena (like $\dot{\varepsilon} \chi \theta \varrho \tilde{\omega} v \tau \iota \nu \tilde{\omega} \nu \dot{\varepsilon} \sigma \tau \iota$ 'it belongs to some enemies') are discussed in [Belov 2015: 262 ff.], where the phonological stress of the indefinite $\tau \iota v \tilde{\omega} v$ is questioned.

${ }^{30}$ See also [Janse 1995/6: 163], who shows that in many cases Greek enclitics have stronger assimilation with the host word ( $\left.\pi \varrho \tilde{\omega} \tau 0 \mu \_\mu \dot{\varepsilon} \nu\right)$ than the orthotonic words. 
These are the IE parallels that Huggard bases his argument on and traces the Hittite system back to. However, we believe that it is exactly these parallels that show that synchronically the Hittite system is radically different from the one which is preserved in Latin and Greek and which is likely to be reconstructed for Narrow IE. Moreover, the Hittite system cannot even be traced back to the Narrow IE one diachronically.

As shown above, in Hittite, indefinite pronouns are both second position and preverbal, which is unreconcilable with the suggested unstressed character. Neither Latin nor Greek display preverbal position of uncompounded wh-phrases (of the type $\tau \iota \varsigma$, quis) functioning as indefinite pronouns, their position is that of Wackernagel second position.

A caveat is due here. Naturally, derived indefinite forms like Latin quidam, quisquam do not attest the constraint - they can be both preverbal and first, but they are stressed. What is significant is that Lat. quis etc. can be only clause second in their indefinite use, and never seem to be clause internal, including the preverbal position.

As for Greek, the placement of $w h$-words used as indefinite pronouns ( $\tau \iota \varsigma$, etc.) can at face value produce the impression of being clause internal and even preverbal as in the following example from Ilias (XII, 8-9):

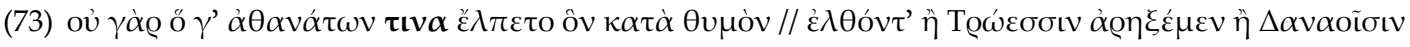

$\begin{array}{llll}\text { où } & \gamma \dot{\alpha} \varrho & \text { ó } & \gamma^{\prime} \\ \text { not.PROCL.PART } & \text { for.ENCL.PART } & \text { who.REL.PRON.NOM.SG.M } & \text { truly.PRAGM.PART.ENCL }\end{array}$

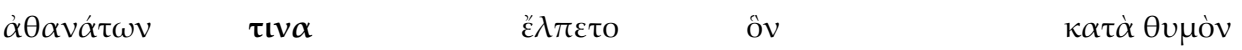

immortals.GEN.PL one.ACC.SG.M.ENCL believe.IMP.3SG his.DEM.PRON.ACC.SG in.the.soul-ACC.SG

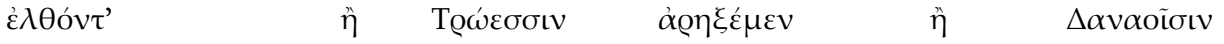

come.ACC.SG.PRTC.AOR either Trojan.DAT.PL bring.aid.INF.AOR either Greek.DAT.PL

"Because he couldn't believe in his soul that it would be one of the immortals, who came to provide [military] assistance to Trojans or Greeks".

Here at first sight the placement of $\tau \iota v \alpha$ is clause internal and even preverbal, but a closer look at the information structure of the clause reveals that $\alpha \theta \alpha v \alpha \dot{\tau} \omega v$, the word immediately preceding $\tau \iota v \alpha$, is contrastively focused as counterexpectant focus. Cross-linguistic studies show that focusing is often marked by insertion of a prosodic boundary immediately in front of the focused constituent in SOV languages [Büring 2009]. Thus such deviating examples are easy to fit into the proposed scheme. We believe that there should be a prosodic boundary to the left of $\alpha \theta \alpha \nu \alpha \dot{\tau} \omega \nu$ triggered by the information structure. Consequently $\tau \iota v \alpha$ is in the expected second position, although the boundary in front of the first position is not clausal. As dramatically different from Greek, Hittite indefinite pronouns are preverbal both when they follow constrastive focus and when they do not.

It is also highly significant that it is the preverbal position which should be primary for Hittite indefinite pronouns. There is not a single OH/OS unambiguous attestation of second position indefinite pronouns, only preverbal ones or ambiguous between preverbal and second position. The only example from the Laws which at first sight produces the impression of unambiguous second position indefinite pronoun is

(74) OH/NS (CTH 291.III) KBo 6.4+ obv. i 4 (\$ 35)

\begin{tabular}{|c|c|c|c|c|}
\hline takku & $\underline{\text { UNUTE }} \underline{\mathrm{MEŠ}}^{-}$ & kuiški & $\underline{\text { našma } \mathrm{GU}_{4}}$ & UDU ANŠE.KUR.RA \\
\hline if & implements & somebody.NOM.SG.C & ox & sheep horse \\
\hline NŠE & wemiya-zi \# & & & \\
\hline
\end{tabular}

ass find-3sG.PRS

"If anyone finds implements or an ox, a sheep, a horse, [or] an ass, ..." (following [Hoffner 1997: 54]). 
However, as [Hoffner 1997: 54] observes, the paragraph it occurs in is a late version of $\S \S 45$ and 71. The OH/OS starting point in either case does not contain a list between the indefinite pronoun and the verb. The word order is the expected OSV one in both cases with the indefinite pronoun ambiguous between second and preverbal position:

(75) OH/OS (CTH 291.III) KBo 6.2+ obv. ii 36 (§ 45)

\begin{tabular}{|c|c|c|}
\hline [takku] & $\bar{a}[\check{s}] s ̌ u^{? 31}$ & $k[u i s ̌ k i$ \\
\hline & goods.ACC.SG.N & somebody.NOM.SG.C \\
\hline
\end{tabular}

"If anyone finds implements, ..." (following [Hoffner 1997: 53]).

(76) OH/OS (CTH 291.III) KBo 6.2+ rev. iii 4 (§ 71)

$\begin{array}{lllll}\text { takku } & \underline{\mathrm{GU}_{4}} \underline{\underline{-}-u n} & \text { ANŠE.[KUR.RA } & \text { ANŠE.GİR.NUN.N]A-an } & \text { ANŠE-in } \\ \text { if } & \text { ox-ACC.SG.C } & \text { horse } & \text { mule-ACC.SG.C } & \text { ass-ACC.SG.C } \\ k \text { kuiški } & \text { wemiya-zi \# } & & \\ \text { somebody.NOM.SG.C } & \text { find-3SG.PRS } & \end{array}$

"If anyone finds a (stray) ox, a horse, a mule (or) an donkey, ..." (following [Hoffner 1997: 54]).

Thus, (74) has nothing to do with the $\mathrm{OH}$ usage. The copies of the $\mathrm{OH} / \mathrm{OS}$ original do not introduce the addition (see [Hoffner 1997: 53, 79]). It appears only in the NH modification of the $\mathrm{OH}$ original combining two earlier paragraphs and reflects $\mathrm{NH}$ usage. Besides, it may simply be a scribe's slip, inserting the list in the wrong place. This is suggested by the following example which shows that scribes could mechanically extend the clause and insert the addition in the wrong place:

(77) OH/NS (CTH 292.II.a.B) KBo 6.26+ obv. ii 23-4 (§ 176a)

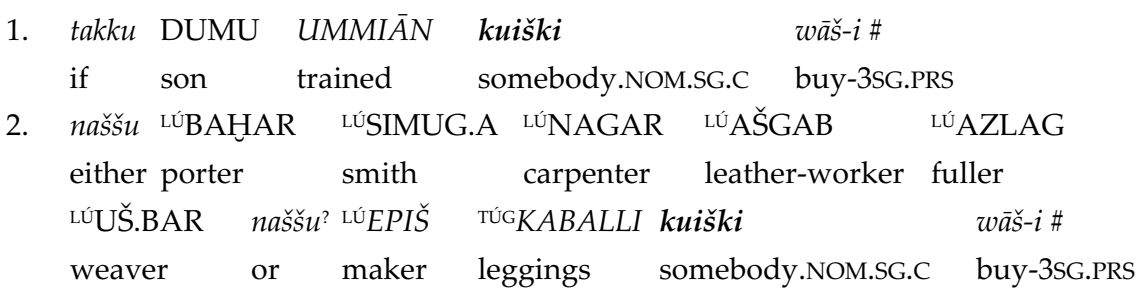

“(1) If anyone buys a trained artisan, (2) either a potter, a smith, a carpenter, a leather-worker, a fuller, a weaver, or a maker of leggings anyone buys, ..." (following [Hoffner 1997: 140-1]).

Here the list inserted after the clause and the indefinite pronoun as well as the verb are repeated after the list. We suppose the same mechanics might be at work for (74) producing the illusion of second position indefinite pronoun in Old Hittite.

Besides, the use of Hittite "indefinite pronouns" in the first position, for which see exx. (62-68) above, is also dramatically different from Latin/Greek model. In Latin/Greek it is usually the wh-phrases in their interrogative meaning that are in the first position. ${ }^{32}$

In Hittite the function is indefinite, but the form is of relative pronouns/ subordinators which thus simply retain one of their prototypical positions after mān "if". What is noteworthy

${ }^{31} U$ UNUTE ${ }^{\mathrm{MES}}$ in NS/OH KBo 6.3+ obv. ii 57.

32 The classic example is (Il. I, 8):

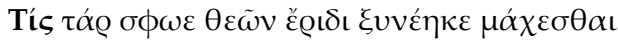

Tís tá@

who.NOM.SG then.PRAGM.PART.ENCL them.ACC.DU god.GEN.PL anger.DAT.SG

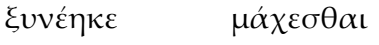

send.AOR.3.SG fight.INF.PRS

"But who among the gods made them fight in anger?" 
diachronically is that the use attested in Latin, Greek and the majority of other IE languages cannot be directly traced to the Hittite usage. In Hittite the use of relative pronouns/subordinators in the function of indefinite pronouns is post-OH and should be considered an independent innovation from the Narrow IE. Hittite attests the use of relative pronouns as indefinite only in post-OH period [CHD sub mān]. The oldest attested Hittite texts (OH/OS originals) have only indefinite pronouns in conditional clauses and after negation markers. Sideltsev's count of $\mathrm{OH} / \mathrm{OS}$ corpus revealed $62 \times m \bar{a} n$ kuiški/kuitki vs $0 \times{ }^{*} m \bar{a} n$ kuiš/kuit. The latter is sporadically attested only in later copies of $\mathrm{OH}$ texts and is very likely to reflect $\mathrm{MH} / \mathrm{NH}$ usage. The statistics is impressive enough to be just a matter of coincidence ${ }^{33}$.

3.1. Moreover, it can be demonstrated that none of Huggard's synchronic Hittitological arguments in favour of indefinite pronouns being unstressed are compelling evidence. His arguments run as follows: apart from being in the second position (for which now see [Sideltsev 2014a]), indefinite pronouns always follow their head noun, indefinite pronouns "participate in the distraction (hyperbaton) of two constituents, whether it be a periphrastic perfect, postpositional phrase, genitival phrase, or a noun phrase composed of an adjective plus noun" [Huggard 2014].

Now we will critically reassess the argument and show that they do not hold. Just like for $m \bar{a} n$ "if/when" and relative pronouns, it can be demonstrated that indefinite pronouns synchronically behave in a very different way from enclitics in the second position and from proclitic $n u$. It is clearly seen in:

(78) MH/MS (CTH 186) HKM 8 obv. 15-16

15. $m \bar{a} n=a n \quad h a n d \bar{a}-\check{s} i$

OPT $=$ him locate-2SG.PRS

16. kuwapiki \# ...

somewhere

"You should locate him somewhere" (following [Hoffner 2009: 99]).

This example shows the difference between phonologically placed second position constituents - in this case =an "him" and syntactically placed second position constituent kuwapiki "somewhere". Whereas the former directly follows its host and stays in the same line, the latter starts a new line, as obviously different from unambiguous enclitics.

The following example is similar. It also unambiguously testifies against another claim of Huggard. The sequence head noun - indefinite pronoun is written over two lines, which is extremely unexpected if the indefinite pronoun is enclitic to the head noun:

(79) $\mathrm{MH} / \mathrm{MS}$ (CTH 188) HKM 46 obv. 15-16

15. man=kan DUTU ${ }^{\check{I}}=\mathrm{B} \quad B E L I=Y A B E L U$

if=LOC Majesty=My lord=my lord

16. kuinki parā nai-tti \#

some.ACC.SG.C out send-2SG.PRS

"If Your Majesty, my lord, were to send some lord, ..." (following [Hoffner 2009: 174]).

The following example demonstrates that even within negative pronouns the indefinite pronoun is not enclitic to the negation marker as it starts a new line:

(80) MH/MS (CTH 186) HKM 30 rev. 16-17

16. kinun $=a=m u \quad n a[m m a] \quad U L$

now $=$ but $=$ me then $\quad$ NEG

${ }^{33}$ Sideltsev proposes to set out the detailed arguments elsewhere. 


\section{7. kuitki h h[a]trā-šsi \#}

anything.ACC.SG.N write-2SG.PRS

"But now you no longer write anything" (following [Hoffner 2009: 154]).

As for indefinite pronoun always following its head noun, the generalization of Huggard is simply too strong. Even in our limited corpus of $\mathrm{MH} / \mathrm{MS}$ letters and instructions there are at least two counterexamples. Contra [Huggard 2014], second position indefinite pronouns precede its head noun in the following examples:

(81) OH-MH/MS (CTH 262) IBoT 1.36 obv. i 57

$m \bar{a} n=w a=[k a] n$ šarā=ma kui-š antūwahha-š handāi-zzi \#

if $=$ QUOT=LOC up=but some-NOM.SG.C man-NOM.SG.C manage-3SG.PRS

"If some man manages (to go) up, ..." (following [Miller 2013: 112-3]).

(82) OH-MH/MS (CTH 262) IBoT 1.36 obv. i 19-20

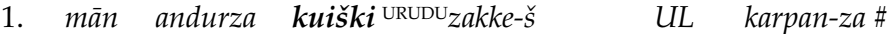
if inside some doorbolt-NOM.SG.C NEG lift-PRTC-NOM.SG.C
2. našma É.NA4KIŠIB kuitki hašš-anzi \#
or storehouse some open-3PL.PRS

“(1) If inside some doorbolt has not been lifted, (2) or if they open some storehouse" (following [Miller 2013: 104-5]).

Both of indefinite pronouns in $(81,82)$ are in the second position. In the following case the indefinite pronoun precedes its head noun in the preverbal position:

(83) OH/OS (CTH 291.I.a.A) KBo 6.2 obv. i 36 (§ 19a)

[(takku LÚ.U $\left.{ }_{19}\right]$ LU-an LÚ-n=aku MU[(NUS-n=aku URUHattuš-az

if free.person man=or woman=or Hattusa-ABL

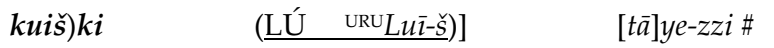

some.NOM.SG.C man Luwian-NOM.SG.C steal-3SG.PRS

"If a Luwian abducts a free person, man or woman, from the land of Hatti, ..." (following [Hoffner 1997: 30]).

Besides, if we interpret predominance of the position after the head NP as indicative of the unstressed character, attributive participles, hummant- "all" and dapiyant- "all" which regularly follow head nouns [Hoffner, Melchert 2008: 271, 339] will also be unstressed.

The final argument of Huggard in favour of indefinite pronouns being unstressed and behaving like an ordinary second position enclitic is that indefinite pronouns "participate in the distraction (hyperbaton) of two constituents, whether it be a periphrastic perfect, postpositional phrase, genitival phrase, or a noun phrase composed of an adjective plus noun" [Huggard 2014].

However, the same distraction can be caused by many other constituents, not only enclitics ${ }^{34}$. It is also important that the same type of connections can be broken in positions different from the second position.

For example, indefinite pronouns break up the nexus noun + adjective. But the same connection is broken up in the following example, although neither indefinite pronouns nor second position enclitics are envolved:

${ }^{34}$ Besides, it is a common fact in the generative literature even on second position enclitics that only those constituents that can be "distracted" in other position, are "distracted" by enclitics [Bošković 2001]. Thus even enclitics do not bring about any unique "distractions". 
(84) NH/NS (CTH 578) KUB 22.61 rev. 18'-19'

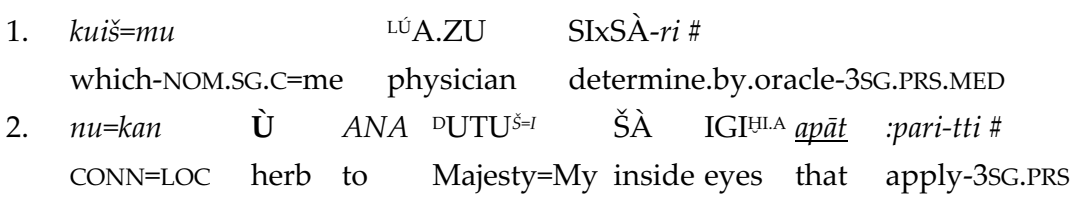

“(1) Which physician is determined by oracle for me (2) will apply that herb (and no other) to His Majesty eyes” (following [Goedegebuure 2013: 32, ex. 20]).

In (84) only the noun Ù "herb" moves to the clause first position whereas the other part of the same NP, pronoun apāt "that", stands preverbally ${ }^{35}$. A similar mechanics lies behind the following example. Here only a part of the NP $k \bar{l} \breve{S} A$ m Kur uttar "this matter of Kur" is fronted to the initial position ( $k \bar{\imath}$ "this"), whereas the rest of the NP ( $\breve{S} A$ m Kur uttar "matter of Kur") is in front of the preverb:

(85) NH/NS (CTH 577) KUB 5.24+ obv. ii 13-14

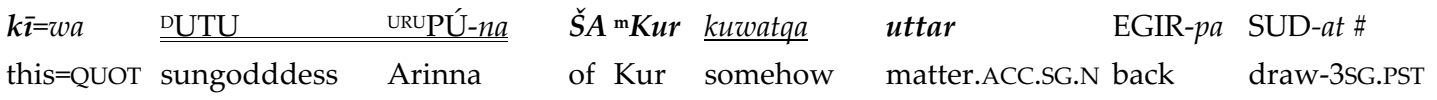

"The Sungoddess of Arinna wanted to prolong this matter of Kur somehow, ..." (following [van den Hout 1995: 256-7; Mouton 2007: 199-200]).

Canonical word order is attested in the lexically identical context from the same text:

(86) NH/NS (CTH 577) KUB 5.24+ obv. ii 19-20

\begin{tabular}{|c|c|c|c|}
\hline$m \bar{a} n=m a$ & DINGIR-LUM & $\check{S} A{ }^{\mathrm{m}} K u r$ & uttar \\
\hline if $=$ but & god & this.GEN.SG of Kur & matter.ACC.SG.N \\
\hline [E]GIR-pa & kuitki & SUD-at \# & \\
\hline & NEG & .ACC.SG.N draw-3SG.PS & \\
\hline
\end{tabular}

back NEG something.ACC.SG.N draw-3SG.PST

"But if the goddess did not at all want to prolong the matter of this Kur, ..." (following [van den Hout 1995: 256-7; Mouton 2007: 199-200]).

The indefinite pronoun might also clause internally break up an NP which it does not belong to. It does so in (85) above where kuwatga is inside part of the NP ( $\breve{S} A$ mKur uttar) and it does it again in the following examples:

(87) NH/NS (CTH 68.E) KUB 6.44+ obv. iv 26'-27'

[nu mān t]uk ANA mKupanta-DLAMMA $\underline{\text { ŠA DUTU } ̌ s=I}$ [(kuiški)

CONN if you to Kupanta-Kurunta of Majesty=My some.NOM.SG.C

HUJL-lu- $n$ 〈memian

bad-ACC.SG.C matter.ACC.SG.C before speak.3sG.PRS

“If someone speaks [an evil] word concerning My Majesty before you, Kupanta-Kurunta, ...” (= rev. iv 28'29’. Following [Friedrich 1926: 136-9; Beckman 1996: 75]).

(88) NH/NS (CTH 76.A) KBo 19.73+ rev. iii 26-27

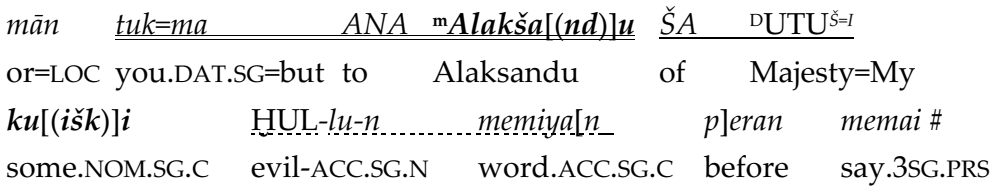

"If someone speaks an evil word concerning My Majesty before you, Alaksandu, ..." (following [Friedrich 1930: 70-1; Beckman 1996: 85]).

35 See [Goedegebuure 2013: 32, ex. 20] for the information structure analysis. 
In both of the examples of $(87,88)$ the indefinite pronoun kuiški breaks up the NP $\breve{S} A$ DUTUŠs HUL-lun memiya $n$ "an evil word concerning My Majesty".

The following example is very curious. It attests the process quite opposite to that postulated by Huggard, indefinite NP (Lúaraš kuiški "some colleague") break up by another NP (Lúari "colleague"):

(89) MH/NS (CTH 260.1) KUB 31.44+ obv. ii 6-7

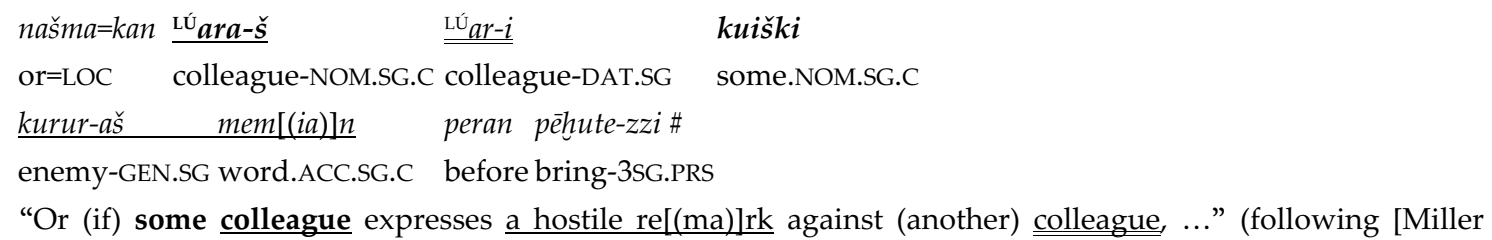
2013: 288-9]).

The example is all the more extraordinary as the indefinite NP was in the second position - before the break up! Should we consider Lúari enclitic on the basis of this example? We suppose not. Other examples involving the indefinite NP break up are:

(90) NH/NS (CTH 380.A) KBo 4.6 obv. 10'-11'

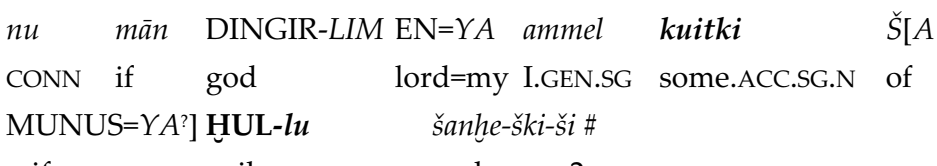

wife=my evil.ACC.SG.N seek-IMPF-2SG.PRS

"If you, O god, my lord, are seeking some evil in my [wife(?)]..." (following [Tischler 1981: 12-3; Singer 2002: 72]).

(91) NH/1NS (CTH 67) KBo 5.4 rev. 21-22

mān tuk=ma kuiški ANA mTargaš[nalli LúKÚR] arāi \#

if you.ACC.SG=but some.NOM.SG.C to Targasnalli enemy arise.3SG!.PRS

“But [if] some [enemy] arises against you, Targasnalli...” (following [Friedrich 1926: 64-5; Beckman 1996: 67]).

Apart from the data about constituent break up by indefinite pronouns or indefinite NP break up by other constituents, there are data that other second position constituents also break up constituents. In the following cases it is the subordinator mahhan "as, when" that breaks up the NP:

(92) NH/NS (CTH 42.A) KBo 5.3+ obv. i 18

nu=tta mān tuel mahhan SAG.DU=KA nakki-š \#

CONN=you if your as head=your heavy-NOM.SG.C

"And if (His Majesty's head is not as dear to you) as your own head is dear to you" (following [G. Wilhelm (ed.), hethiter.net/: CTH 42 (INTR 2013-02-24), Beckman 1996: 24; CHD L-N: 365]).

(93) NH/NS (CTH 42.A) KBo 5.3+ obv. i 22

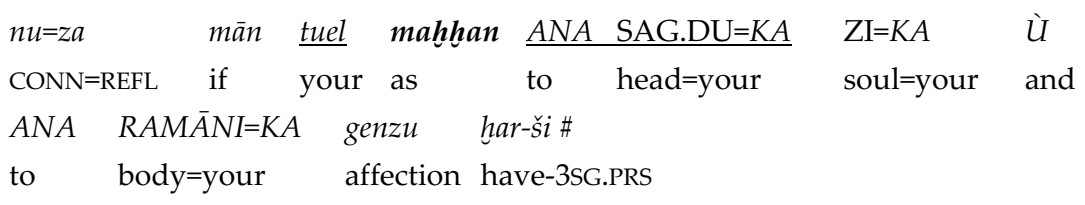

"If (you are not well-disposed to the person of My Majesty, the soul of My Majesty, and the body of My Majesty and do not me in a protective embrace) in the same way as you are well-disposed to to your person, soul and body" (following [G. Wilhelm (ed.), hethiter.net/: CTH 42 (INTR 2013-02-24), Beckman 1996: 24]).

See above fn. 18 for the distribution of mahhan "as, when" in the clause second position is the least common of the three of the subordinators. It looks like second position subordinators 
are the only type of second position constituents that have not yet been assessed as enclitic. And we believe ex. (92) cannot be interpreted in this way.

Another nexus which is often broken up by second position indefinite pronouns is NP postposition. But the same connection can be broken by indefinite pronouns within the clause, i.e. without any connection with the second position, as the following case shows:

(94) NH/OS (CTH 291.III) KBo 6.4+ obv. i 4 (§ III)

$\begin{array}{lllllll}\text { [takku=kan } & \text { LÚDAM.GÀR } & \text { URUH]atti } & \underline{\underline{a} s ̌ s ̌ u w-a s ̌ ~} & k u i s ̌ k i & \underline{a n d a} & k u e n-z i \# \\ \text { if=LOC } & \text { merchant } & \text { Hittite } & \text { goods-LOC.PLsomebody.NOM.SG.C } & \text { in } & \text { kill-3sG.PRS }\end{array}$

"[If] anyone kills a Hittite [merchant] in the midst of his goods, ..." (following [Hoffner 1997: 19-20])36.

In the following example it is the preverbal indefinite pronoun that breaks up the NP + postposition construction:

(95) NH/NS (CTH 89.A) KUB 21.29+ rev. iv 8-9

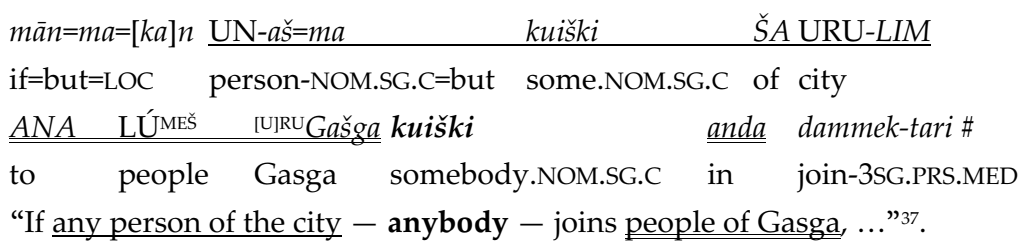

An example not involving an indefinite pronoun and involving a very clear fronting of the NP, but not the postposition which stays in the preverbal position with the ensuing split of the postpositional phrase is:

(96) MH/NS (CTH 261.1.B) KUB 13.2+ rev. iv 13'-14'

[m]aniyahhiya=ta=kkan kue É.GAL-LìH.A-Tİ ÉHI.A BELUTI=ya [(and)]a]\#

province.LOC.SG=you=LOC which.NOM.PL.N palace.officials houses lord=and in

"(And you shall inquire regularly into) the palaces and noble estates that are in your [p]rovince, ..." (following [Miller 2013: 232-3]).

Ex. E (KUB 31.89(+)) of the text where (96) comes from, see [Miller 2013: 232], has canonical word order as it starts in rev. iv 6' with [Éha]lentūwa=ya=ta=kkan É.GALHI.[A. According to Miller [2013: fn. 452], maniyahhi- presumably followed and was lost in the lacuna. The regular position of the locative immediately in front of the postposition is also seen in the same text:

(97) MH/NS (CTH 261.1.B) KUB 13.2+ rev. iv 9'-10'

\section{[...] É.GAL-LİHI.A kue maniyahhiya $[(\underline{a n}) \mathrm{da}] \#$}

palaces which.NOM.PL.N province.LOC.SG in

"(You must [(also)] keep an eye on al[1) the ...] (and) the palaces [(i)n your] province" (following [Miller 2013: 232-3]).

An analogous case of split of postpositional phrase is not involving indefinite pronouns is:

(98) MH/NS (CTH 264.A) KUB 13.4 obv. ii 19

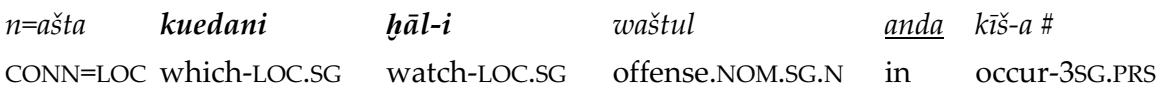

"In which watch an offense occurs, ..." (following [Miller 2013: 256-7]).

36 The example is even more extraordinary in view of the older version of the same text (KBo 6.2 obv. i 3) where $\bar{a}$ ššuwaš anda "in the midst of (his) goods" was not employed.

${ }^{37}$ Cf. [González Salazar 1994: 164, 167]: “Anybody of the city or anybody (else)”. 
Thus the Latin and Greek system of stressed wh-words vs unstressed wh-words in the second position functioning as indefinite pronouns which Huggard and Becker very explicitly base their arguments on is only very distantly cross-linguistically similar to the attested Hittite system. The first difference of Hittite from Greek/Latin system is that indefinite pronouns behave in syntactical terms identically to relative pronouns and some subordinators. The second is that Hittite indefinite pronouns are not limited to the second position, they are at least as frequently attested in the preverbal position. These two major differences show it beyond any reasonable doubt that Hittite indefinite pronouns are not unstressed.

The diachronic inner Hittite data show that the peculiarities of Hittite indefinite pronouns appeared within the history of Hittite and cannot be traced back to the Narrow IE system retained in Latin, Greek and other IE languages. Thus, the Hittite system and the Narrow IE one must be regarded as independent innovations from the Indo-Hittite system.

\section{Consolidation of Prosodic Accounts}

It is particularly instructive to confront independently formulated arguments of Huggard, Becker and Kloekhorst in favour of unstressed character of relative pronouns, subordinator $m \bar{a} n$ "if/when" and indefinite pronouns and see that they plainly contradict each other and make all the three hypotheses even less tenable than they are separately. Thus, Kloekhorst argues that frequently spelt plene mahhan "when, as" is stressed as different from consistently spelt plene mān "if, when". However, mahhan is optionally second position which in the logic of Huggard and Becker is one of the arguments in favour of second position constituents being unstressed!

\section{Syntactic Account of the Data}

Thus, if one does not a priori tie in second position with unstressability 38 , there is no independent ground to posit lack of lexical stress on indefinite and relative pronouns in Hittite. If they were just unstressed and if the second position was intimately connected with unstressability, how can it be explained that they are not always in the second position, just like regular Wackernagel clitics? On the contrary, they behave like second position stressed verbs in Germanic/Kashmiri and stressed second position relative pronouns/subordinators ${ }^{39}$ in Kashmiri where they can occupy other positions [Bošković 2001; Munshi, Bhatt 2009], see, e.g., for Kashmiri relative phrases:

(99) [sami:r-an $\quad\left[\begin{array}{llll}\text { yosi } & k i t a: b\end{array}\right]$ ra:j-as $\quad$ dits $] \quad\left[\begin{array}{ll}\text { so } & \text { kita:b... }\end{array}\right]$

Samir-ERG which book.F Raj-DAT give.PST.F.SG that book.F

"The book that Samir gave to Raj, that book...." [Munshi, Bhatt 2009: 215].

5.1. Hittite Second Position: Structural Account. What is then the explanation of the Hittite second position system? Starting from the distribution we suggest the following linear positions in the left periphery of the Hittite clause. Each position is marked by [ ]. They need not be necessarily filled in a clause, the only exception is the obligatory position 3 :

\footnotetext{
${ }^{38}$ For which there is no independent cross-linguistic support.

${ }^{39}$ More precisely relative phrases, complementizers yeli "when", "until”, "since”, agar "if", and comparatives are clause second [Munshi, Bhatt 2009: 214-8]. However, all these constituents can appear not only in the second position, but also in the first one, but not further down [Munshi, Bhatt 2009: 215]. Thus the constraint is more accurately described as $1 / 2$ constraint. The same is applicable to many Hittite second position constituents.
} 


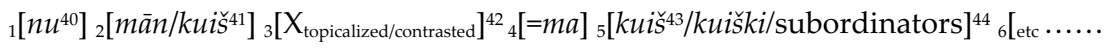

The description implies that $-(m) a$ as well as $k u i \check{s}^{45} / k u i{ }^{2} k i /$ subordinators have fixed positions in a Hittite clause that do not depend on phonology. There are two arguments in favour of this. The first one is that $-(m) a$ occupies position 4 only if it is topicalizing/contrastive. It is contrastively focusing, it can be clause internal, see [Sideltsev, Molina forthcoming]. Thus, its position in the clause is determined by its information structure status, and not by phonology. The second argument is that other second position constituents like kuiš46/kuiški/subordinators are actually $1 / 2$ position, i.e. all of them, albeit with different frequency, can occupy not only the second, but also the first position. So the same account is applicable to them as the one put forward for Kashmiri subordinators and relative pronouns, see [Munshi, Bhatt 2009].

\section{Summary}

Thus we have shown that there is no unambiguous synchronic evidence in favour of Hittite second position constituents (as well as the constituents that do not count as the first position for $-m a$ ) being unstressed. In the Indo-European perspective the Hittite system of second position indefinite and relative pronouns cannot be directly equated with and traced back to the system attested in the Narrow Indo-European languages of wh-words being unstressed in the indefinite function. The Hittite second position system of indefinite and relative pronouns and the Narrow Indo-European system represent independent innovations and provide yet another evidence in favour of Indo-Hittite hypothesis.

\section{References}

Alp 1991 - Alp S. Hethitische Briefe aus Mașat-Höyük, Ankara, 1991.

Becker 2014 - Becker K. Zur Semantik der hethitischen Relativsätze (Studien zur historisch-vergleichenden Sprachwissenschaft 5), Hamburg: Baar, 2014.

Beckman 1996 - Beckman G. Hittite Diplomatic texts (SBL Writings from the Ancient World 7), Atlanta.

Belov 2015 - Белов А. М. Аревнегреческая и латинская просодика (мора, ударение, ритмика). M.: Aсаdетіа. [Belov A. Drevnegrecheskaja i latinskaja prosodika (mora, udarenije, ritmika). Moscow. 2015]

Bošković 2001 - Bošković Ž. On the nature of the syntax-phonology interface: Cliticization and related phenomena. London: Elsevier, 2001.

CHD - H. Güterbock, H. Hoffner, T. van den Hout (eds.), The Hittite Dictionary of the Oriental Institute of the University of Chicago, Chicago: The Oriental Institute of the University of Chicago, 1989-.

del Monte 1986 - del Monte G.F. Il trattato fra Muršili Il di Ȟattuša e Niqmepa' di Ugarit (OAC 18), Roma, 1986.

Friedrich 1926 - Friedrich I. Staatsverträge des Hatti-Reiches in hethitischer Sprache. 1. Teil (MVAeG 31/1), Leipzig, 1926.

Friedrich 1930 - Friedrich I. Staatsverträge des Hatti-Reiches in hethitischer Sprache. 2. Teil (MVAeG 34/1), Leipzig, 1926.

${ }^{40}$ Wackernagel enclitics cliticize to the first filled position in the clause, i.e. to the first available of the five.

${ }^{41}$ In indeterminate clauses.

42 The position must be filled in any clause. In case of absence of topicalized or contrasted constituents, any constituents - closest to the position - fills position 3.

${ }^{43}$ In determinate clauses.

${ }^{44}$ All the constituents from this position can be optionally preverbal.

${ }^{45}$ In determinate clauses.

${ }^{46}$ In determinate clauses. 
Garrett 1990 - Garrett A. J. The Syntax of Anatolian Pronominal Clitics. Ph.D. Diss., Harvard University, 1990.

Goedegebuure 2009 - Goedegebuure P. Focus structure and Q-words questions in Hittite. Linguistics 47 (2009), 945-969.

Goedegebuure 2013 - Goedegebuure P. Hittite Noun Phrases in Focus. In: S. W. Jamison, H. C. Melchert, B. Vine (eds.), Proceedings of the 24th Annual UCLA Indo-European Conference. Bremen, 27-45, 2013.

Goedegebuure 2014 - Goedegebuure P. The use of demonstratives in Hittite: deixis, reference and focus (StBoT 55), Wiesbaden, 2014.

Goetze 1967 - Goetze A. Die Annalen des Mursilis, Darmstadt, 1967.

González Salazar 1994 - González Salazar J. M. Tiliura, un ejemplo de la política fronteriza durante el imperio hitita (CTH 89). AuOr 12 (1994), 159-176.

Haegeman 1996 - Haegeman L. Object Clitics in West Flemish. In: Halpern A. L., Zwicky A. M. (eds.), Approaching Second: Second Position Clitics and Related Phenomena, (CSLI-LN 61) Stanford, 1996. P. 135-164.

Halpern 1996 - Halpern A. Introduction. In: Halpern A. L., Zwicky A. M. (eds.), Approaching Second: Second Position Clitics and Related Phenomena, (CSLI-LN 61). Stanford, 1996. P. ix-xxiii.

Haug forthcoming - Haug D. T. T. PIE *kwi-/kwo-: Interrogative, indefinite or both? (In print).

HED - Puhvel J. Hittite Etymological Dictionary (Trends in Linguistics, Documentation), Berlin/New York, 1984-.

Held 1957 - Held W. H. Jr. The Hittite Relative Sentence. Language 33 (1957), 4/2.

Hoffner 1997 - Hoffner H. A. Jr. The Laws of the Hittites: A Critical Edition (DMOA 23), Leiden, 1997.

Hoffner 2009 - Hoffner H. A. Jr. Letters from the Hittite Kingdom (SBL Writings from the Ancient World 15), Atlanta, 2009.

Hoffner, Melchert 2008 - Hoffner H. A. Jr., Melchert H. C. A Grammar of the Hittite Language, Part 1: Reference Grammar, Winona Lake, Indiana, 2008.

Holmberg 2013 - Holmberg A. Verb Second. In: T. Kiss, A. Alexiadou (eds.), Syntax - an International Handbook of Contemporary Syntactic Research. 2nd edition, Berlin: Walter de Gruyter, 2013.

Huggard 2013 - Huggard M. More on kuit: Causal clauses in Hittite. In: ECIEC 32, June 21-24, 2013 (handout).

Huggard 2014 - Huggard M. On Semantics, Syntax and Prosody: a Case Study in Hittite and other IndoEuropean languages. In: ECIEC 33, June 6-8, 2014 (handout).

$\mathrm{HW}_{2}$ - J. Friedricht / A. Kammenhubert (eds.), Hethitisches Wörterbuch, Heidelberg, 1975-.

Janse 1995/6 - Janse M. Phonological aspects of clisis in ancient and modern Greek. Glotta 73, 1/4 (1995/6): 155167.

Kloekhorst 2014 - Kloekhorst, A. Accent in Hittite: A Study in Plene Spelling, Consonant Gradation, Clitics, and Metrics (StBoT 56), Wiesbaden: Harrasowitz, 2014.

LSJ - Liddle H. G., Scott R., Johnes H. S, McKenzie R. A Greek - English Lexicon. Oxford: Oxford University Press, 1996.

Melchert 2009 - Melchert H. Craig. Discourse Conditioned Use of Hittite -ma. In: E. Rieken, P. Widmer (eds.), Pragmatische Kategorien. Form, Funktion und Diachronie, Akten der Arbeitsteigung der Indogermanischen Gesellschaft vom 24. bis 26. September 2007 in Marburg, Wiesbaden, 2009. P. 187-195.

Miller 2013 - Miller J. Royal Hittite Instructions (SBL Writings from the Ancient World 31), Atlanta, 2013.

Mouton 2007 - Mouton A. Rêves hittites (CHANE 28), Leiden/Boston, 2007.

Munshi, Bhatt 2009 - Munshi S., Bhatt R. Two locations for negation. Evidence from Kashmiri. Linguistic Variation Yearbook 9 (2009). P. 205-240.

Otten 1981 - Otten H. Die Apologie Hattusilis III (StBoT 24), Wiesbaden, 1981.

Otten 1988 - Otten H. Die Bronzetafel aus Bogazkoy (StBoT Bh 1), Wiesbaden, 1988.

Probert 2006 - Probert Ph. Ancient Greek Accentuation: Synchronic Patterns, Frequency Effects and Prehistory. Oxford: Oxford University Press, 2006.

Salisbury 2005 - Salisbury D. Local adverbs in Neo-Hittite, Ph.D., Chapel Hill, 2005.

Samuels 2005 - Samuels B. On the Left Periphery in Anatolian. Linguistic Analysis 35/1 (2005): $275-297$.

Sideltsev 2014a - Sideltsev A. Clause internal and clause leftmost verbs in Hittite. AoF 41/1 (2014): 80-111.

Sideltsev 2014b - Sideltsev, A. Wh-in-situ in Hittite. In: Tiplogija morfosintaksicheskix parametrov. Moscow: MGGU, 2014. P. 198-222.

Sideltsev, Molina forthcoming - Sideltsev A., Molina M. Review of Kloekhorst, Accent in Hittite. In: Babel und Bibel.

Singer 2002 - Singer I. Hittite Prayers (SBL Writings from the Ancient World 11), Atlanta, 2002. 
Tischler 1981 - Tischler J. Das hethitiche Gebet der Gassulijawija (IBS 37), Innsbruck, 1981.

Tronsky 1962 - Тронский И. М. Аревнегреческое ударение. М.-А.: АН СССР, 1962. [Tronsky I. M. Drevnegrecheskoje udarenije. Moscow / Leningrad, 1962.]

van den Hout 1995 - van den Hout Th. Der Ulmitešub-Vertrag (StBoT 38), Wiesbaden, 1995.

Yates 2014 - Yates A. Anatolian "Indeterminate" Relative Clauses Revisited: Syntax, Semantics, and the "HeldGarrett rule". In: OLT 41, 6 December, 2014 (handout).

Zaliznjak 2008 - Зализняк А. А. Древнерусские энклитики. М.: Языки славянской культуры, 2008. [Zaliznjak A. A. Drevnerusskije enklitiki. Moscow, 2008.]

Zimmerling 2013 - Циммерлинг А. В. Системы порядка слов славянских языков в типологическом аспекте. М.: Языки славянской культуры, 2013. [Zimmerling A. V. Sistemy porjadka slov slavjanskix jazykov v tipologicheskom aspekte. Moscow, 2013]

Zimmerling, Kosta 2013 - Zimmerling, A., Kosta P. Slavic Clitics: a Typology. STUF 66/2 (2013): 178-214.

А. В. Сидельцев, М. А. Молина, А. М. Белов. Синтаксис или фонология? Проклитики, клитики и ударение в хеттском языке.

Статья рассматривает синтаксис та̄n 'если', патma 'затем', паšma 'или', перфективирующего kāša/kāšma, относительных и неопределенных местоимений, а также некоторых подчинительных союзов в хеттском. В ряде недавних работ выдвигается гипотеза, что синтаксис данных слов в предложении определяется полностью или частично фонологически, то есть их проклитической либо энклитической природой. В нашей работе проанализированы и опровергнуты аргументы в пользу фонологического анализа, показано, что хеттские данные не поддерживают гипотезы упомянутых авторов. Имеющиеся данные предлагается объяснять чисто синтаксически. В индоевропейской перспективе хеттский язык радикальным образом отличается от прочих индоевропейских языков типа древнегреческого, которым свойственно как раз энклитическое употребление неопределенных местоимений: все факты, которые на первый взгляд объединяют хеттский с остальным и.-е. ареалом, при более внимательном рассмотрении оказываются вторичными и независимыми инновациями хеттского, с одной стороны, и узкого и.-е. ареала, с другой.

Ключевые слова: клитики, вторая позиция, энклитики, проклитики, ударение, относительные местоимения, неопределенные местоимения. 